\title{
Health, Personality Disorders, Work Commitment and Training to Employment Transitions*
}

\author{
Alexander Patzina ${ }^{1}$, Hans Dietrich ${ }^{1}$ and Anton Barabasch ${ }^{1}$ \\ ${ }^{1}$ Education, Training and Employment over the Life Course, Institute for Employment Research, Germany \\ E-Mail: alexander.patzina@iab.de, hans.dietrich@iab.de, anton.barabasch@iab.de
}

This version: November 15, 2021

\begin{abstract}
This study analyzes the influence of mental and physical health, coping abilities, cooperativeness, and work commitment on the transition from apprenticeship training to a first job. In doing so, we first investigate transitions to regular employment within six months post-graduation. Second, we analyze gapless transitions from training to a first job. Third, we investigate transitions to a decent first job. This study draws on a unique dataset of 1,061 individuals from Germany that combines rich survey and register data. The baseline survey takes place during the last year of training for these individuals and contains information on their schooling, health, personality disorders and work attitudes. The register data measure the training environment and labor market outcomes. The results from linear probability models reveal that only physical health is associated with finding a first job within six months. Physical and mental health are associated with gapless transitions. Overall health, coping abilities and work commitment are important in terms of finding decent employment. However, when conditioning on individual and training firm characteristics, these associations are weakened and become statistically insignificant. Thus, the constructs under study might drive school graduates into certain training firms and occupations leading to decent first jobs. Fourth, our results indicate that the effect of overall health on gapless transitions is largest for individuals with higher levels of education, while the overall health effect is almost zero for those who are least educated. Thus, this study provides evidence of a cumulative disadvantage of the least educated in the school-to-work transition.
\end{abstract}

\section{Keywords}

Anxiety and Depression; Apprenticeship Training; Health; Cooperativeness; Coping; School-to-Work Transition; SF-12, Work Commitment

* We would like to thank Teresa Friedrich for her valuable feedback. Furthermore, we thank participants of the Annual Conference of the Society for the Advancement of Socio-Economics (SASE), Transition in Youth conference and TREE conference for their valuable comments. 


\section{Introduction}

The literature unambiguously shows that school-to-work transition outcomes are crucial for status attainment (e.g., Müller \& Gangl, 2003), adolescents' mental development (e.g., Schoon \& Mortimer, 2017) and the life course development of health and subjective well-being (e.g., Kratz \& Patzina, 2020; Leopold \& Leopold, 2018). Labor market research indicates that starting positions at labor market entry have long-lasting impacts on individuals' careers because bad school-to-work transition outcomes lead to precarious employment throughout the employment career (e.g., Scherer, 2004). Further, the literature emphasizes that educational dropout has lasting negative effects on wage development and employment opportunities (e.g., Borgna \& Struffolino, 2017; Campbell, 2015; Patzina \& Wydra-Somaggio, 2020).

Many studies in this area emphasize that the attainment of educational certificates is of pivotal importance for successful transitions into the labor market, i.e., to obtain good starting positions (e.g., Fossati et al., 2020; Gebel, 2015; Jacob \& Solga, 2015). Additionally, the literature indicates that school performance (i.e., good grades) in upper-secondary education predicts high wages at labor market entry (e.g., Hansen et al., 2021; Wydra-Somaggio \& Seibert, 2010). An increasing body of research also emphasizes that certain personality facets, like self-efficacy, have a direct effect on school-to-work transition outcomes (e.g., access to vocational education and training (VET) or labor market entry), independent of degree attainment and school performance (e.g., Pinquart et al., 2003; Ng-Knight \& Schoon, 2017; Protsch \& Dieckhoff, 2011). Furthermore, personality traits and emotional problems have an indirect effect on school-to-work transition outcomes that operate through school performance and degree attainment (e.g., DiGiunta et al., 2013; Duchesne \& Ratelle, 2010). In addition to degree attainment and the role of personality, research suggests that mental health constitutes an important determinant of successful school-to-work transition. For instance, some research indicates that mental health problems lead to educational dropout (e.g., Cornaglia et al., 2015; McLeod \& Fettes, 2007), influence school performance (e.g., Eisenberg et al., 2009) and have a direct effect on higher education enrollment decisions (Zheng, 2017). A driving force behind mental health being crucial for educational decision making may be that particularly depressive symptoms influence individuals' school performance and perceptions of the future (e.g., Leykin et al., 2011; Roepke \& Seligman, 2016).

This study connects to the briefly outlined research stream and provides an in-depth analysis of the transition of apprenticeship training graduates in Germany into the labor market. The two main research questions that this study aims to answer are as follows. Do mental and physical health, personality disorders, and work attitudes affect training-to-employment transitions? Are these factors, in addition to the learning environment, school leaving certificates and school performance, important? Answering the above two research questions is important because socioemotional and health factors can be seen as useful resources in the status attainment process (e.g., Haas, 2006). Additionally, the literature also 
emphasizes that health constitutes an important selection mechanism that influences school performance and educational dropout (e.g., McLeod \& Fettes, 2007). Thus, if this study finds a net effect of health, personality disorders and work values in addition to the learning environment and poor schooling outcomes, then these findings suggest a double disadvantage for individuals who already, based on their poor schooling outcomes, face disadvantages, at labor market entry, in the school-to-work transition.

To answer the proposed research questions, this study uses novel data on apprentices from the dual apprenticeship training system, which combines survey and register data. The survey data come from a representative sample of apprentices interviewed in their final year of training (2016 graduation cohort). In addition to social background characteristics and schooling outcomes (grades and degrees), the baseline survey contains the SF-12 (Radoschewski \& Bellach, 1999), a well-established construct that measures physical and mental health, and a well-established screening tool for anxiety and depression risks (HSCL-10, Derogatis et al., 1974). Moreover, this baseline survey measures personality disorders (cooperativeness and coping) based on a scale developed by Parker et al. (2004). Furthermore, the baseline survey measures work attitudes based on the work involvement scale (Warr et al., 1979).

In the baseline survey, $69.9 \%$ of individuals gave their consent to match baseline information to register-based social security data, the Integrated Employment Biographies (IEB; see Berge et al., 2021) data, in which we observe the learning environment (i.e., training firm sizes and mean wage levels of training firms) and three school-to-work transition outcomes. First, we analyze whether individuals find a job within six months after completing VET. Second, we investigate whether individuals find a job immediately after their apprenticeship; i.e., we investigate whether apprentices have no employment interruption at all. Third, we analyze their transitions into decent first jobs.

Based on rich linked survey and register data, linear probability models and an analysis of the net effect of usually not jointly observed individual resources (i.e., mental and physical health, personality disorders, and work attitudes) on school-to-work transition outcomes, this study advances our knowledge on the role of noncognitive and socioemotional factors at a crucial life course stage. Investigating this crucial period in individuals' life is important because inequalities are likely to accumulate over the life course (e.g., Di Prete \& Eirich, 2006). Thus, even small differences at early ages can lead to great inequality at later life course stages (e.g., Dannefer, 2003). 


\section{Institutional Setting}

This research focuses on transitions from the apprenticeship training system into the labor market. In Germany, apprenticeship training constitutes one central provider of postsecondary education in addition to university education. Within the apprenticeship training system, those individuals who decide to leave school apply for apprenticeship positions, of which there are over 300 available. Firms constitute crucial actors in this system because they select the applicants to hire. This selection process highly depends on school performance, degree attainment and noncognitive skills (e.g., Protsch \& Solga, 2015). Attaining formal degrees from the apprenticeship training system is particularly important because the labor market is highly stratified and licensed (e.g., Bol \& Weeden, 2015; for a detailed overview of the German training system, see, for example, Solga et al., 2014).

The data of this study contain apprentices who graduated in 2016 and entered a first job between 2016 and 2018. From 2005 to 2019, youth unemployment rates decreased in Germany from 15.5\% to $5.8 \%$, respectively. In the same period, long-term youth unemployment (as the share of young unemployed individuals, longer than 6 months) decreased from 54\% to 38\% (Dietrich et al., 2018; Dietrich et al., 2021). This finding indicates, however, that even in times of low unemployment, a substantial subgroup of young individuals faced severe problems (re)entering the labor market. Mental health problems could be one reason for such reduced transition rates. In addition to possible rising mental health problems within the youth population, job centers were still less prepared to recognize and support young people with mental health problems (Reissner et al., 2014).

\section{Theoretical Considerations and Empirical Findings}

\subsection{Entry into VET}

A well-established finding of early school-to-work transition research indicates that degree attainment within the general educational system eases transitions in upper-secondary education (e.g., Müller \& Shavit, 1998; Müller \& Gangl, 2003). This finding is also repeatedly corroborated by more recent work that focuses particularly on the German VET system (e.g., Dietrich et al., 2019; Holtmann et al., 2017; Jacob \& Solga, 2015; Zimmermann \& Skrobanek, 2015). Moreover, this research emphasizes that school performance constitutes another important driver of postsecondary educational decisions. Furthermore, other research indicates that the socioeconomic background (e.g., Dietrich et al. 2019) and migration experiences (e.g., Diehl et al., 2009; Seibert et al., 2009) of individuals influence their successful transitions into VET. In addition to parental education and income, parental unemployment strongly influences individuals' transitions into VET (e.g., Lindemann \& Gangl, 2019). Furthermore, the regional characteristics of local labor markets determine individuals' integration into VET (e.g., Hillmert et al. 2017; Kleinert \& Jacob, 2013). Interestingly, structural conditions when leaving school interact with socioeconomic background characteristics. Lindemann and Gangl (2019) show, for instance, that the effect of parental unemployment is most pronounced in downward-turning local economies. 
This classical strand of sociological research has become increasingly complemented by research on cognitive and noncognitive factors, mainly scrutinizing the direct effects of these factors, net of school achievement and degree attainment. Thus far, this research on school-to-training transitions indicates that for those individuals who decide to leave lower-secondary school, their competences (i.e., math and reading skills) and noncognitive characteristics (i.e., conscientiousness and self-esteem) appear to not be important predictors for transitions into VET in Germany (Holtman et al., 2017). Protsch and Dieckhoff (2011) investigate the role of Big Five personality traits and find that personality traits have no universal effect on VET transitions. However, when analyzing within school degree transitions, personality traits like conscientiousness, emotional instability, and openness, in addition to school performance and degree attainment, appear to be important predictors. Moreover, Zimmermann and Skrobanek (2015) show the additional and direct effect of general self-efficacy (i.e., the belief that one's own actions can alternate the environmental context and certain life outcomes) on transitions into VET. In their study, the self-efficacy effect appears to be rather substantial, as the average marginal effect is one-fifth of the school degree effect in their sample.

\subsection{Grades, Formal Degrees and Labor Market Entry}

Research on labor market entry cohorts provides evidence that attaining educational degrees through the VET system eases transitions into the labor market. For instance, Scherer's (2005) findings indicate that not attaining vocational education (i.e., school dropouts or graduates with lower-secondary degrees) in Germany is associated with long durations between dropping out or graduating and finding a substantial first job. Interestingly, in her analysis, individuals with intermediate secondary degrees and vocational education have the highest transition rates into stable first employment. This finding aligns well with the literature on general vs. vocational education, which indicates, for many societal contexts, an early labor market advantage of VET (e.g., Forster et al., 2016). Kratz et al.'s (2019) findings for Germany indicate that this early labor market advantage becomes even stronger across cohorts. In addition, Becker and Blossfeld (2021) show that the quality of entry positions (measured by occupational prestige) decrease only for those individuals least educated (i.e., for individuals without vocational degrees) in Germany across labor market entry cohorts (1950 to 2010). The analysis of transitions to first jobs is important because the quality of entry positions is crucial for the development of stable labor market careers (Scherer, 2004).

In addition to degrees, labor market research also indicates that school performance (i.e., grades) during postsecondary education influences individuals' transitions into the labor market. Hoeschler and Backes-Gellner (2018) show that with increasing grade point average (GPA), the likelihood of an apprentice receiving a job offer by his or her training firm at the end of apprenticeship training (i.e., retention offer) increases. Pinquart et al. (2003) show that in the German context, even school grades influence school-to-work transition outcomes, as good students show the lowest probabilities of youth 
unemployment at age 21 years. In addition to job offers and employment opportunities, research also suggests that with increasing GPA, labor market entry wages increase (Wydra-Somaggio \& Seibert, 2010). This GPA effect even persists in models conditioning on training firm size, educational degree and training occupation.

\subsection{Health and Labor Market Entry}

Although a long tradition of research on the causal relationship between (un)employment and (mental) health exists (e.g., Jahoda et al., 1932/1971; Krug \& Eberl, 2018), that on the impact of (mental) health on labor market entry is scarce. To understand the potential impact of (mental) health for our study that focuses on transitions from the education system, research on the selection mechanism of health appears most important. In contrast to the causation literature, which mainly focuses on individuals who have already made the transition from education to work and which mainly investigates the causal effect of (un)employment on (mental) health, work on the selection mechanisms primarily focuses on withinschool processes.

The prominent research on health selection within educational systems stresses that childhood health conditions causally influence educational attainment and health in adolescence and adulthood. McLeod and Fettes (2007) were among the first to show, based on longitudinal data (Children of the National Longitudinal Surveys of Youth data from the U.S.), that poor mental health during childhood and adolescence has a negative effect on schooling outcomes (i.e., high school completion and college entry). Interestingly, the authors also show that mental health works through educational expectations, net of school performance and disruptive behavior (e.g., suspension from school). Thus, mental health appears to involve alternating perceptions about the future, which turns out to be important for actual educational behavior. Furthermore, individuals with childhood mental health problems appear to perform worse in school than do those who develop mental health problems during adolescence (McLeod \& Fettes, 2007). McLeod et al. (2012) also show that mental health is important for GPA. Analyses indicate that while depression has no direct effect on GPA, attention problems (attention-deficit/hyperactivity disorder (ADHD)), among them being delinquent behaviors and substance use, predict poor GPA. Note, however, that depression appears to have a proxy effect on schooling outcomes, as depressive symptoms have a negative and statistically significant effect on school outcomes when other mental health domains and behavioral variables are not included in the modeling.

Evensen's (2019) study adds to the findings from the U.S. in showing that poor mental health is associated with poor school achievement. In her study, the author further shows that the effects of poor mental health are not constant across grades, as mental health effects appear largest at the lower end of the distribution. In addition, Evensen shows that mental health problems more often occur among lowachieving school students, which corroborates earlier work by Haas (2006), who, in his study, emphasizes that socioeconomic differences in early childhood health exist and accumulate over the life 
course. This accumulation process leads to poor schooling and poor health in adolescence. Thus, poor health and schooling interact with each other, thereby strongly influencing status attainment within a society.

As research indicates that individuals' health constitutes a driving force of schooling outcomes, an interesting question becomes whether health can still predict transitions to first jobs. If pure selection and sorting according to health into schooling outcomes and learning environments occur, then we would not find any association between health outcomes and labor market entry after accounting for GPA, schooling degrees and environmental factors (e.g., firm size or training firm wage levels).

\subsection{Personality disorders, Work Commitment and Labor Market Entry}

For labor market entry, a study of Germany (Pinquart et al., 2003) indicates that particularly high academic self-efficacy beliefs at age 12 to 15 years reduce unemployment risks and increase job satisfaction at age 21 years. For Swiss apprentices, Hoeschler and Backes-Gellner (2018) find that grit (a concept strongly related to self-efficacy) and Big Five personality traits constitute very important predictors of receiving job offers at the end of apprenticeship training. For England Ng-Knight and Schoon (2017) provide an analysis of "not in employment, education or training" (NEET) risks from ages 16 to 20 years and internal locus of control (i.e., the belief in which individuals think they have control over the outcomes of certain life events). One main finding constitutes that with increasing levels of internal locus of control, the risk of labor market exclusion between the ages 16 to 20 years decreases. While the literature review shows that previous work already provides some insights on the influence of certain personality facets on school-to-work transition outcomes, research on coping abilities and cooperativeness (i.e., the constructs used in this study) is scarce.

In contrast to the literature on personality traits, research on the role of work commitment in the school-to-work transition is scant. However, a seminal study by Bielby and Bielby (1984) on female college graduates in the U.S. indicates that with increasing levels of work commitment, women exhibit a higher attachment to the labor market than do men. According to this empirical finding, we also expect that high levels of commitment ease transition into the labor market for apprentices in Germany. Moreover, it appears noteworthy that the employed measure in our study deviates from the standard sociological construct. While most sociological research on work commitment focuses on women and uses a measure that approximates “... the subjective relative importance of work over family as a source of well-being and satisfaction" (Gangl \& Ziefle, 2015, p. 531), our study relies on a psychological measure that aims to identify the general attitude of individuals toward work (Warr \& Wall, 1979).

\subsection{Cumulative (Dis)Advantage and Effect Heterogeneity}

Thus far, we have presented evidence on the important predictors of successful school-to-work transitions. The following interesting question, however, remains. To what extent does schooling success 
accumulate with health, personality disorders and work commitment? Based on notions from cumulative (dis)advantage theory (e.g., Di Prete \& Eirich, 2006), we expect that individuals with good schooling outcomes also benefit the most from good health, personality, and work commitment. The work of Protsch and Dieckhoff (2011) on access to VET hints at potential effect heterogeneity. In contrast, the notion of cumulative (dis)advantage makes it possible to hypothesize that health, personality traits and work commitment constitute resources that have a stronger impact on less educated individuals. This resource substitution argument (e.g., Ross and Mirowsky 2011) might lead to successful transitions, particularly among low-educated individuals with good health, favorable personality traits, and high work commitment.

Furthermore, we can also argue that because of preselection into school degrees, school performance and VET programs and institutions, the measures under study have no impact at all on transitions into the labor market. However, this is a strong assumption that constitutes an empirical open question. Through our study, we answer this question and further test for potential effect heterogeneity across school degrees.

In sum, our study provides novel insights on an important transition of a large share of German school leavers. In scrutinizing the role of health, personality disorders and work commitment, we advance our current knowledge on the noncognitive dimensions of disadvantage in the field of transition research. Moreover, in investigating the direct effects of health, personality disorders and work commitment (net of schooling outcomes and selection into the learning environment), our study scrutinizes a potential double disadvantage for individuals at labor market entry who already face disadvantages in the schoolto-work transition based on their poor schooling outcomes.

\section{Methods}

\subsection{The Jugalo Study and Sample}

The Jugalo Study (on youth unemployment and mental health) combines rich survey data with register data from the Federal Employment Agency. While the register data measure labor market outcomes, the survey data measure the key explanatory variables used in this study (the consent for data linkage in this study was 69.9\%). The rich baseline survey comprises various measures on health, personality disorders and work commitment. Some of these measures constitute the key explanatory variables of this research. In addition, the survey contains information on critical life events (e.g., school experience scale, parental divorce, or loss of family members), health-related behavior (e.g., substance consumption), social support (e.g., social support appraisal scale), and sociodemographics (e.g., parental education, migration background, and household composition).

To retrieve our final analytical sample, we employ two restrictions. We employ only data from individuals who state their consent for the data linkage, and we analyze only full cases. From the original 
survey ( $\mathrm{N}=1,801), 1,259$ individuals gave consent for the data linkage (69.9\%). A selectivity analysis revealed that consent for data linkage depends on the coping abilities of individuals, school degree and performance. Thus, individuals with better coping abilities, a high school diploma and better grades are slightly overrepresented. However, the selection model explains only $2.6 \%$ of the variation in consent propensity, which is rather low and suggests that the analytic sample is not highly selective based on the main explanatory variables as well as other observables. Furthermore, school degree and performance are controlled for in the final specifications of our model, which reduces the likelihood of potential bias. Regarding the decent job model, we perform a data-driven selection: for technical reasons, the register data do not deliver information on the mean wage level of some training firms leading to the exclusion of further 162 cases. The final sample includes 1,061 individuals with information on job transitions from the register data.

\subsection{Measures}

Dependent variables: This study employs three outcome measures that stem from the register data. First, we analyze whether an apprentice finds a first job within six months of completing VET. Second, we analyze whether an apprentice finds a first job without employment interruption, i.e., directly after completing VET. In doing so, we scrutinize whether young individuals have a smooth school-to-work transition. Additionally, in the German case, this often suggests that apprentices are retained by their training firm-a circumstance for which many apprentices strive. Figure 1 shows that over $75 \%$ of the sample has a gapless school-to-work transition (e.g., immediate retention after training or no search time). This finding reflects the previously mentioned fact that from 2015 to 2018, entries into youth unemployment in Germany were scarce, and almost every apprenticeship graduate found employment. Third, we analyze whether apprentices access a decent first job. We define a decent first job as employment that lasts longer than 182 days and pays an above-average wage. To determine what constitutes an above-average wage, we rely on a full sample of all apprentices of the 2016 graduation cohort, which enables us to calculate the median wages of labor market entrants conditioned on their training occupation. We use the German classification of occupations KLDB-1988 to retrieve median wages on a three-digit training occupation level. We merge this information based on these codes to our analytic sample. 


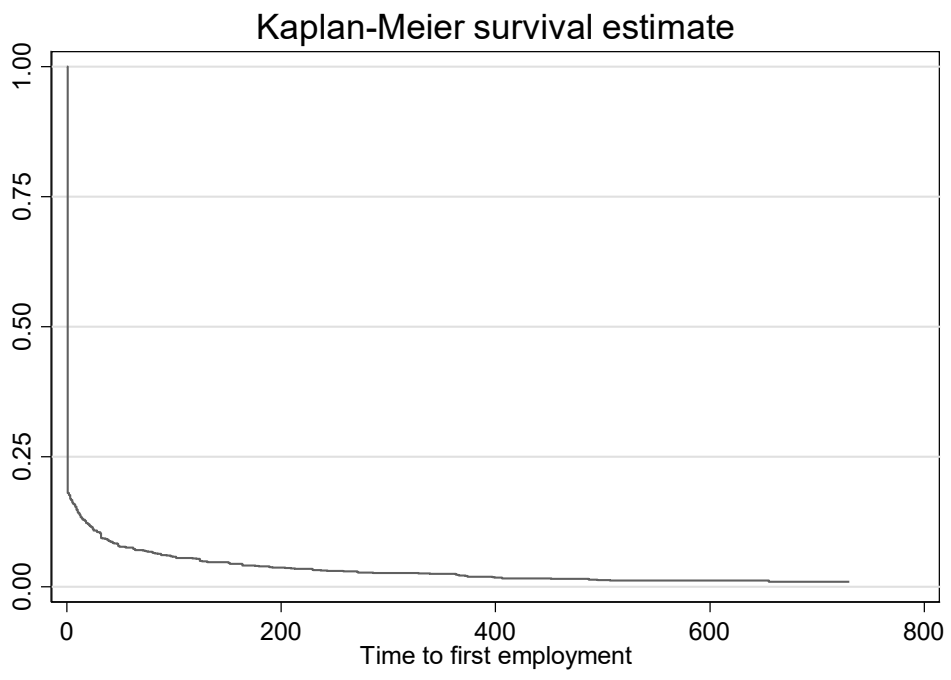

Figure 1. Time to first employment after completing apprenticeship training. Source: Own calculations based on data from the Jugalo Study.

Health: We employ indicators that approximate mental, physical and overall health. To measure anxiety and depression risks, we employ the HSCL-10 scale, which constitutes a reduced form of the Hopkins Symptom Checklist (Derogatis et al. 1974). In our study, the ten employed items reveal high internal validity, as indicated by Cronbach's alpha of 0.856. To measure overall health, we employ the SF12, which constitutes a reduced form of the SF-36 (Radoschewski \& Bellach 1999). This measure also reveals high internal validity, as indicated by Cronbach's alpha of 0.875 . We additionally employ the two subscales of the SF-12 that approximate the physical (pSF-12) and mental health (mSF-12) domains.

Personality disorders: We employ a subscale (11 items) of the personality functioning scale according to Parker et al. (2004), which measures two domains of personality. First, the scale delivers a measure for cooperativeness. The scale approximates individuals' beliefs about problems in terms of their interactions with friends, colleagues and strangers in general. Second, the Parker scale delivers a measure for coping. This measure is highly related to other personality constructs like self-efficacy and internal locus of control. The internal validity of the employed constructs is moderate. Cronbach's alpha for the cooperativeness subscale is 0.665 , while that for the coping subscale is 0.630 .

Work commitment: We employ the Work Involvement Scale (Warr et al. 1979), which is based on six items. These items measure work commitment, as individuals evaluate statements on the importance of being employed, mental burden of unemployment, and anxiousness during (potential) periods of unemployment. Furthermore, individuals rate items that ask whether working is the most important thing to do in life and if they would work despite high unemployment benefits or winning the lottery. Cronbach's alpha of the Warr scale in our data is 0.747.

As all internal validity measures indicate good internal consistency, we construct additive measures (i.e., we build sum scores ranging from 1 to 4 or 5 depending on the response categories of the items). In 
the analyses, we use z-standardized measures, which have the advantage that the results are comparable across the different scales and models employed. Table 1 provides an overview of all dependent variables (see Panel A) and all unstandardized distributions of explanatory variables (see Panel B).

Table 1. Distribution of health, personality disorders and work commitment scores in the analytical sample.

\begin{tabular}{|c|c|c|c|c|}
\hline & Mean & Std. Dev. & Min. & Max. \\
\hline \multicolumn{5}{|l|}{ Panel A: Dependent Variables } \\
\hline Finding a first job within 6 months & 0.961 & - & 0 & 1 \\
\hline Finding a first job without employment interruption & 0.800 & - & 0 & 1 \\
\hline Finding a decent first job & 0.717 & - & 0 & 1 \\
\hline \multicolumn{5}{|l|}{ Panel B: Explanatory Variables } \\
\hline Anxiety and depression (HSCL-10) & 1.543 & 0.491 & 1.000 & 3.900 \\
\hline Overall health (SF-12) & 3.805 & 0.481 & 1.444 & 4.667 \\
\hline Physical health (pSF-12) & 3.866 & 0.575 & 1.250 & 5.000 \\
\hline Mental health (mSF-12) & 3.756 & 0.577 & 1.600 & 5.000 \\
\hline Coping ability (Parker) & 3.085 & 0.463 & 1.400 & 4.000 \\
\hline Cooperativeness (Parker) & 3.439 & 0.391 & 1.500 & 4.000 \\
\hline Work Commitment Scale (Warr) & 4.126 & 0.647 & 1.000 & 5.000 \\
\hline $\mathrm{N}$ & \multicolumn{4}{|c|}{1,061} \\
\hline
\end{tabular}

Data: the Jugalo Study.

Control variables: As important sociodemographics, we consider gender, migration background measured with a dummy variable indicating non-German citizenship, birth year, social origin (i.e., a dummy indicating whether an apprentice stems from a welfare benefit recipient household), and a dummy indicating East Germany. Moreover, full models include the educational level, performance and a dummy for prior VET education. Furthermore, we consider a dummy variable indicating whether the interview is an online survey (the baseline is a paper-and-pencil survey). As important training environment characteristics, we consider firm size and median wage levels.

\subsection{Analytical strategy}

We analyze the impact of health, personality disorders and work commitment on all three outcomes separately. We employ linear probability models in which we separately introduce the measures under study. A final full model always includes the significant coefficients of the partial models. We conduct this workaround twice for each outcome because we present bivariate associations and the net effect while conditioning on control variables. In further analyses, we also acknowledge the sequential nature of the second and third analysis steps (i.e., finding a first job without employment interruption and a decent first job). However, the results from sequential logistic regression models do not substantially differ from those based on linear probability models. The results from this workaround are available upon request.

Additionally, we conducted a factor analysis to elaborate on the interdependence between the used constructs. This workaround revealed that the HSCL-10 and SF-12 approximate one latent construct of health. This has two implications. First, for our modeling. If we were to find statistically significant correlations of the HSCL-10 and SF-12 in the partial models, the full model should only include one of 
both variables. Second, at young ages, it appears that individuals' mental and physical health are strongly correlated.

\section{Results}

\subsection{Finding a First Job within 6 Months}

Table 2 shows the results of the linear regression models. While Panel A shows bivariate associations among health, personality disorders, work involvement and finding a first job within six months, Panel B displays the results from regressions that adjust for the characteristics of individuals and the learning environment. Panel A shows that mental health, personality traits and work involvement are not associated with finding a first job within six months. Only with increasing levels of physical health does the likelihood of finding a job increase (see Model 3 of Table 2). Panel B indicates that this association holds when we condition our models on the characteristics of individuals and the learning environment. Thus, individuals with poor physical health have trouble finding employment under very prosperous labor market conditions. As the literature also indicates that individuals with health problems are likely to be low-performing school students, these results hint at a double disadvantage for low-achieving youth. 
Table 2. Finding a first job within six months.

$$
\text { (1) }
$$

(3)

(4)

\section{Panel $A$}

Anxiety and depression

Mental health

Physical health

Overall health

Work Commitment Scale

Coping ability

Cooperativeness

0.004

(0.006)

(0.006)
$0.015^{* *}$

(0.006)

0.010

(0.006)
0.002

(0.006)

\begin{tabular}{|c|c|c|c|c|c|c|}
\hline $\begin{array}{l}\text { Adj.-R }{ }^{2} \\
\text { F-Value }\end{array}$ & $\begin{array}{l}0.002 \\
2.322\end{array}$ & $\begin{array}{l}0.002 \\
2.248\end{array}$ & $\begin{array}{l}0.008 \\
5.169\end{array}$ & $\begin{array}{l}0.005 \\
3.452\end{array}$ & $\begin{array}{l}0.002 \\
2.218\end{array}$ & $\begin{array}{l}0.001 \\
1.425\end{array}$ \\
\hline \multicolumn{7}{|l|}{ Panel B } \\
\hline Anxiety and depression & $\begin{array}{c}0.006 \\
(0.006)\end{array}$ & & & & & \\
\hline Mental health & & $\begin{array}{c}0.002 \\
(0.006)\end{array}$ & & & & \\
\hline Physical health & & & $\begin{array}{l}0.012^{* *} \\
(0.006)\end{array}$ & & & \\
\hline Overall health & & & & $\begin{array}{c}0.008 \\
(0.006)\end{array}$ & & \\
\hline Work Commitment Scale & & & & & $\begin{array}{c}0.002 \\
(0.006)\end{array}$ & \\
\hline Coping ability & & & & & & $\begin{array}{c}-0.004 \\
(0.007)\end{array}$ \\
\hline Cooperativeness & & & & & & $\begin{array}{c}-0.001 \\
(0.007) \\
\end{array}$ \\
\hline $\mathrm{N}$ persons & 1,061 & 1,061 & 1,061 & 1,061 & 1,061 & 1,061 \\
\hline Adj.- $R^{2}$ & 0.003 & 0.002 & 0.005 & 0.003 & 0.002 & 0.001 \\
\hline F-value & 1.123 & 1.081 & 1.243 & 1.144 & 1.083 & 1.050 \\
\hline
\end{tabular}

Note: Results from linear probability models. Coefficients of z-standardized variables; standard errors in parentheses; constant not shown; significance levels: ${ }^{*} \mathrm{p}<0.10,{ }^{* *} \mathrm{p}<0.05$, and ${ }^{* * *} \mathrm{p}<0.01$. The results from sequential logistic regression do not substantially differ and are available upon request. Full regression results in Table A1 of the Appendix.

Panel A controls: method effects. Panel B controls: educational level, educational performance, second VET, learning environment (training firm size and mean wage level training firm), sociodemographics (social origin, birth year, gender, migration background, and East Germany dummy), and method effects. Data: the Jugalo Study 


\subsection{Finding a First Job without Employment Interruption}

Table 3 shows the results of the linear regression models. The bivariate associations depicted in Panel A indicate statistically significant correlations of the constructs under study. Only work commitment is not statistically significantly associated with gapless transitions to first jobs. The results indicate that with increasing overall (mental or physical) health, the likelihood of transitions to first jobs without employment interruption increases. Additionally, the bivariate associations indicate that with increasing levels of cooperativeness and coping abilities, the likelihood of gapless transitions increases. When we jointly test for overall health and personality traits, however, the model indicates that only overall health remains statistically significant, and the coefficient hardly changes, indicating that overall health rather than personality traits is important for gapless transitions.

Panel B of Table 3 shows the regression results that account for the important characteristics of individuals and the learning environment. While the results indicate that the health measures are only weakly affected by the inclusion of these variables, associations among personality traits become statistically insignificant, and in particular, the coefficient of cooperativeness converges to zero. Thus, the association between personality traits and gapless transitions appears to be mediated by individual and firm characteristics, while overall health is directly associated with gapless transitions to a first job. Again, this finding hints at a double disadvantage for low-achieving youth in the school-to-work.

\subsection{Finding a Decent First Job}

Table 4 shows the results of linear regression models that investigate associations among health, personality disorders, work commitment and the likelihood of finding a decent first job. Panel A depicts bivariate associations and shows that almost every construct under study is statically significantly associated with the outcome. Only the SF-12 dimension measuring mental health is not significantly related to the outcome. Panel A shows that with increasing levels of overall (mental or physical) health, the likelihood of finding a decent first job increases. With increasing levels of work commitment, the likelihood of finding a decent first job also increases. Regarding personality traits, only coping abilities are positively related to finding a decent first job. When investigating the joint predictive power of overall health, work commitment and personality traits (Table 4; full model), the findings suggest that only coping abilities are statistically significantly associated with transitions to a decent first job. While the coefficient of overall health and work commitment is reduced by almost half, that of coping ability is only slightly affected.

Panel B of Table 4 shows the results of models that account for the characteristics of individuals and training firms. This part of Table 4 indicates that after accounting for school performance, educational degree and training firm (among other control variables; see the footnote), the coefficients of all constructs are significantly reduced and no longer statistically significant. Given the empirical evidence that good training firms (i.e., firms that invest in the human capital of their apprentices) lead to high 
wages after graduation (see, for instance, Dietrich et al., 2016), these findings strongly suggest that individuals with good overall health, high coping ability and high levels of work commitment select into firms that provide a smooth transition into the labor market and that lead to good starting points. Thus, as starting points in the labor market are crucial for career development (e.g., Scherer 2004), selection based on health, personality disorders and work commitment after individuals finish high school has the potential to introduce long-term inequality within labor markets.

Table 3. Finding a first job without employment interruption.

\begin{tabular}{|c|c|c|c|c|c|c|c|}
\hline & $(1)$ & $(2)$ & (3) & $(4)$ & $(5)$ & $(6)$ & Full \\
\hline \multicolumn{8}{|l|}{ Panel A } \\
\hline Anxiety and depression & $\begin{array}{c}-0.054^{* * *} \\
(0.012)\end{array}$ & & & & & & \\
\hline Mental health & & $\begin{array}{l}0.062^{* * *} \\
(0.012)\end{array}$ & & & & & \\
\hline Physical health & & & $\begin{array}{l}0.051^{* * *} \\
(0.012)\end{array}$ & & & & \\
\hline Overall health & & & & $\begin{array}{l}0.068^{* * *} \\
(0.012)\end{array}$ & & & $\begin{array}{l}0.061^{* * *} \\
(0.013)\end{array}$ \\
\hline Work Commitment Scale & & & & & $\begin{array}{c}0.019 \\
(0.012)\end{array}$ & & \\
\hline Coping ability & & & & & & $\begin{array}{l}0.030^{* *} \\
(0.013)\end{array}$ & $\begin{array}{c}0.011 \\
(0.013)\end{array}$ \\
\hline Cooperativeness & & & & & & $\begin{array}{r}0.023^{*} \\
(0.013) \\
\end{array}$ & $\begin{array}{c}0.020 \\
(0.013) \\
\end{array}$ \\
\hline Adj.-R ${ }^{2}$ & 0.017 & 0.023 & 0.016 & 0.028 & 0.001 & 0.010 & 0.030 \\
\hline F-Value & 10.296 & 13.442 & 9.350 & 16.431 & 1.671 & 4.637 & 9.256 \\
\hline \multicolumn{8}{|l|}{ Panel $B$} \\
\hline Anxiety and depression & $\begin{array}{c}-0.047^{* * *} \\
(0.013)\end{array}$ & & & & & & \\
\hline Mental health & & $\begin{array}{l}0.055^{* * *} \\
(0.012)\end{array}$ & & & & & \\
\hline Physical health & & & $\begin{array}{l}0.041^{* * *} \\
(0.012)\end{array}$ & & & & \\
\hline Overall health & & & & $\begin{array}{l}0.059^{* * *} \\
(0.012)\end{array}$ & & & $\begin{array}{l}0.056^{* * *} \\
(0.013)\end{array}$ \\
\hline Work Commitment Scale & & & & & $\begin{array}{c}0.015 \\
(0.012)\end{array}$ & & \\
\hline Coping ability & & & & & & $\begin{array}{c}0.016 \\
(0.013)\end{array}$ & $\begin{array}{c}0.001 \\
(0.014)\end{array}$ \\
\hline Cooperativeness & & & & & & $\begin{array}{c}0.020 \\
(0.013) \\
\end{array}$ & $\begin{array}{c}0.015 \\
(0.013) \\
\end{array}$ \\
\hline $\mathrm{N}$ persons & 1,061 & 1,061 & 1,061 & 1,061 & 1,061 & 1,061 & 1,061 \\
\hline Adj.-R ${ }^{2}$ & 0.053 & 0.059 & 0.050 & 0.061 & 0.041 & 0.044 & 0.060 \\
\hline F-value & 3.452 & 3.749 & 3.326 & 3.863 & 2.902 & 2.963 & 3.621 \\
\hline $\begin{array}{l}\text { Note: Results from linear prob } \\
\text { not shown; significance levels } \\
\text { substantially differ and are av } \\
\text { Panel A controls: method effec } \\
\text { environment (training firm siz } \\
\text { migration background, and Ea }\end{array}$ & $\begin{array}{l}\text { Ddels. Coef } \\
0,{ }^{* *} \mathrm{p}<0 \\
\text { on reques } \\
B \text { controls } \\
\text { an wage le }\end{array}$ & $\begin{array}{l}\text { ents of z-s } \\
\text { and }{ }^{* * *} p \\
\text { all regress } \\
\text { ucational }\end{array}$ & $\begin{array}{l}\text { dardize } \\
\text { o.01. Th } \\
\text { results } \\
\text { el, educ }\end{array}$ & $\begin{array}{l}\text { iables; } \\
\text { ults fron } \\
\text { ble A2 } \\
\text { al perfo }\end{array}$ & $\begin{array}{l}\text { lard err } \\
\text { quential } \\
\text { Appen } \\
\text { ce, secc } \\
\text { cial ori }\end{array}$ & $\begin{array}{l}\text { n parenth } \\
\text { tic regre } \\
\text { ET, learn } \\
\text { inth }\end{array}$ & $\begin{array}{l}\text { es; constan } \\
\text { on do not } \\
\text { inder, }\end{array}$ \\
\hline
\end{tabular}


Table 4. Finding a decent first job.

\begin{tabular}{lllllll}
$(1)$ & $(2)$ & $(3)$ & $(4)$ & $(5)$ & $(6)$ & Full \\
\hline
\end{tabular}

\section{Panel $A$}

Anxiety and depression

Mental health

Physical health

Overall health

Work Commitment Scale

Coping ability

Cooperativeness

\begin{tabular}{lc}
\hline Adj.-R & \\
F-value & 0.002 \\
\hline Panel $B$ & 1.841 \\
Anxiety and depression & \\
& -0.013 \\
Mental health & $(0.014)$
\end{tabular}

Mental health

Physical health

Overall health

Work Commitment Scale

Coping ability

Cooperativeness

$-0.026^{*}$

$(0.014)$

(0.014)

$0.042^{* * *}$

$(0.014)$
0.020

$(0.015)$

(0.014)

0.014

$(0.014)$

(0.014)

$0.045^{* * *} \quad 0.036^{* *}$

$(0.015) \quad(0.016)$

$0.011 \quad 0.007$

(0.015) (0.015)

$\begin{array}{llllll}-0.000 & 0.007 & 0.004 & 0.001 & 0.009 & 0.010 \\ 0.844 & 4.680 & 3.058 & 1.711 & 4.372 & 3.166\end{array}$

$\begin{array}{llllll}-0.000 & 0.007 & 0.004 & 0.001 & 0.009 & 0.010 \\ 0.844 & 4.680 & 3.058 & 1.711 & 4.372 & 3.166\end{array}$

\begin{tabular}{llllllll} 
N persons & \multicolumn{1}{c}{} & & & $(0.015)$ & $(0.015)$ \\
Adj.-R & 1,061 & 1,061 & 1,061 & 1,061 & 1,061 & 1,061 & 1,061 \\
F-value & 0.064 & 0.064 & 0.066 & 0.065 & 0.065 & 0.065 & 0.065 \\
\hline
\end{tabular}

Note: Results from linear probability models. Coefficients of z-standardized variables; standard errors in parentheses; constant not shown; significance levels: ${ }^{*} \mathrm{p}<0.10,{ }^{* *} \mathrm{p}<0.05$, and ${ }^{* * *} \mathrm{p}<0.01$. The results from sequential logistic regression do not substantially differ and are available upon request. Full regression results in Table A3 of the Appendix.

Panel A controls: method effects. Panel B controls: educational level, educational performance, second VET, learning environment (training firm size and mean wage level training firm), sociodemographics (social origin, birth year, gender, migration background, and East Germany dummy), and method effects. Data: the Jugalo Study 


\subsection{Heterogeneity across School Degree Levels}

This section presents the heterogeneous effects of physical and overall health by school degree level. We interact only constructs with the level of schooling for which we find statistically significant coefficients in the full models presented in Sections 5.1. to 5.3. Low and medium school degree levels refer to the German "Hauptschule" and "Realschule", respectively, while a high level refers to "Abitur". Employing interaction terms gives us the opportunity to elaborate on the potential double disadvantages for lowachieving youth in the school-to-work transition.

Figure 2 shows the effect of physical health on finding a first job within six months given the educational level. The main finding shows that the effect of physical health among Hauptschule and Realschule graduates appears most important, while physical health has no effect on the Abitur population. This finding indicates that individuals with poor physical health and low educational achievement have more problems accessing the labor market. Moreover, this finding indicates that less educated individuals are more likely to end up in physically demanding jobs, and as a consequence, physical health gains more importance for that particular group. This result is in line with findings from life course research (Kratz et al., 2019). Note that the effects of physical health are very small, which is not surprising, however, because in our observation window characterized by an extensive demand for qualified workers, almost everyone in our sample finds employment within six months.

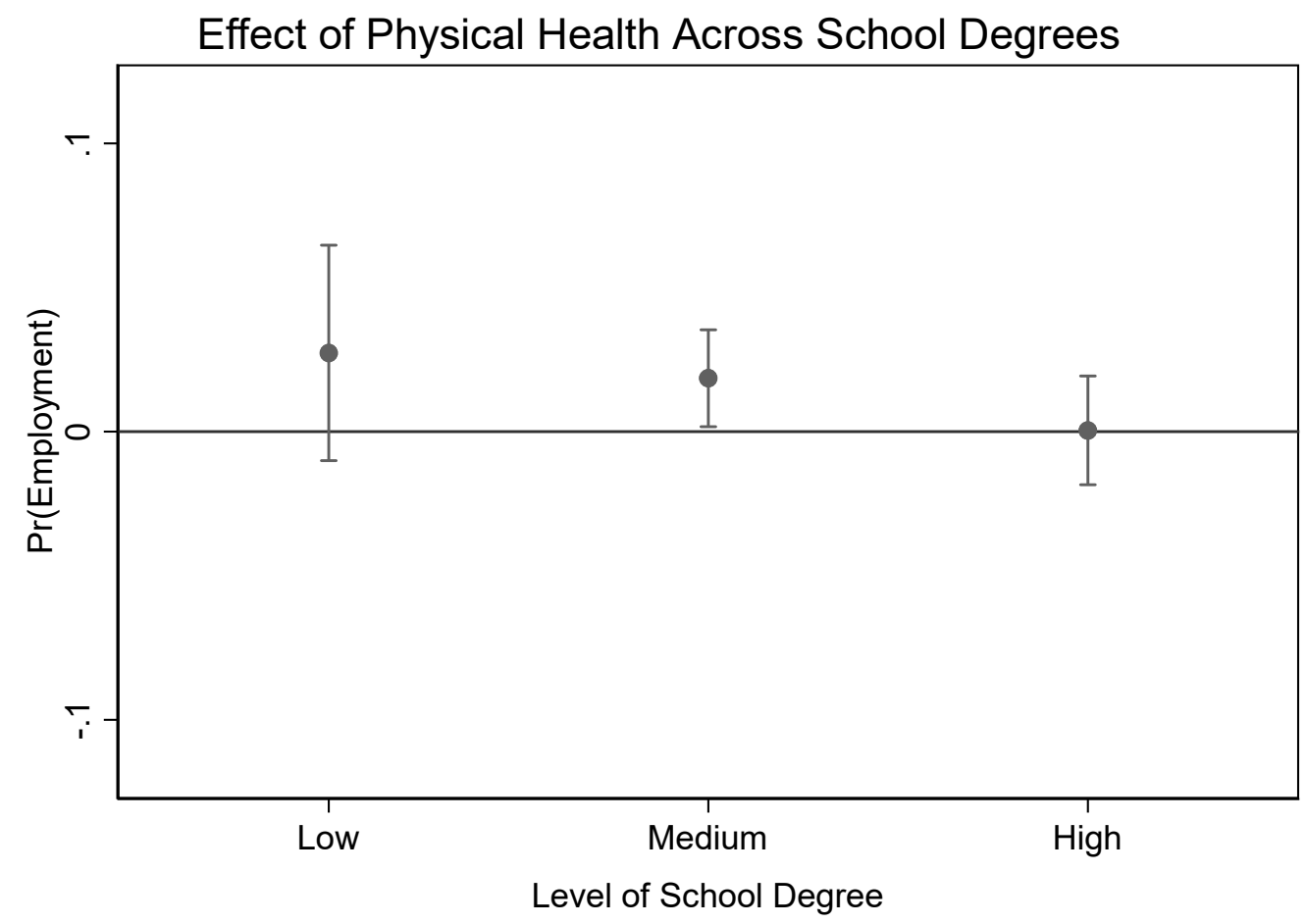

Figure 2. Effects of physical health on finding a first job within six months according to educational level. Full regression results in Table A4 of the Appendix. Source: Own calculations based on data from the Jugalo Study. 
Figure 3 shows the effect of overall, mental and physical health on finding a first job without employment interruption across different educational levels. The presented findings indicate that the most disadvantaged group in the school-to-work transition, namely, Hauptschule graduates, does not profit from good overall health, while with increasing overall health, the likelihood of gapless transitions into the labor market increases for individuals with a Realschule or Abitur degree. The presented findings in Figure 3 indicate a cumulative advantage process of individuals with good schooling outcomes and good health in the school-to-work transition.

Figure 3 also indicates that the overall health pattern is driven by the mental health of individuals. Thus, mental health appears most important for direct transitions from training to a first job, and individuals with a Realschule or Abitur degree appear to profit most from good mental health conditions.
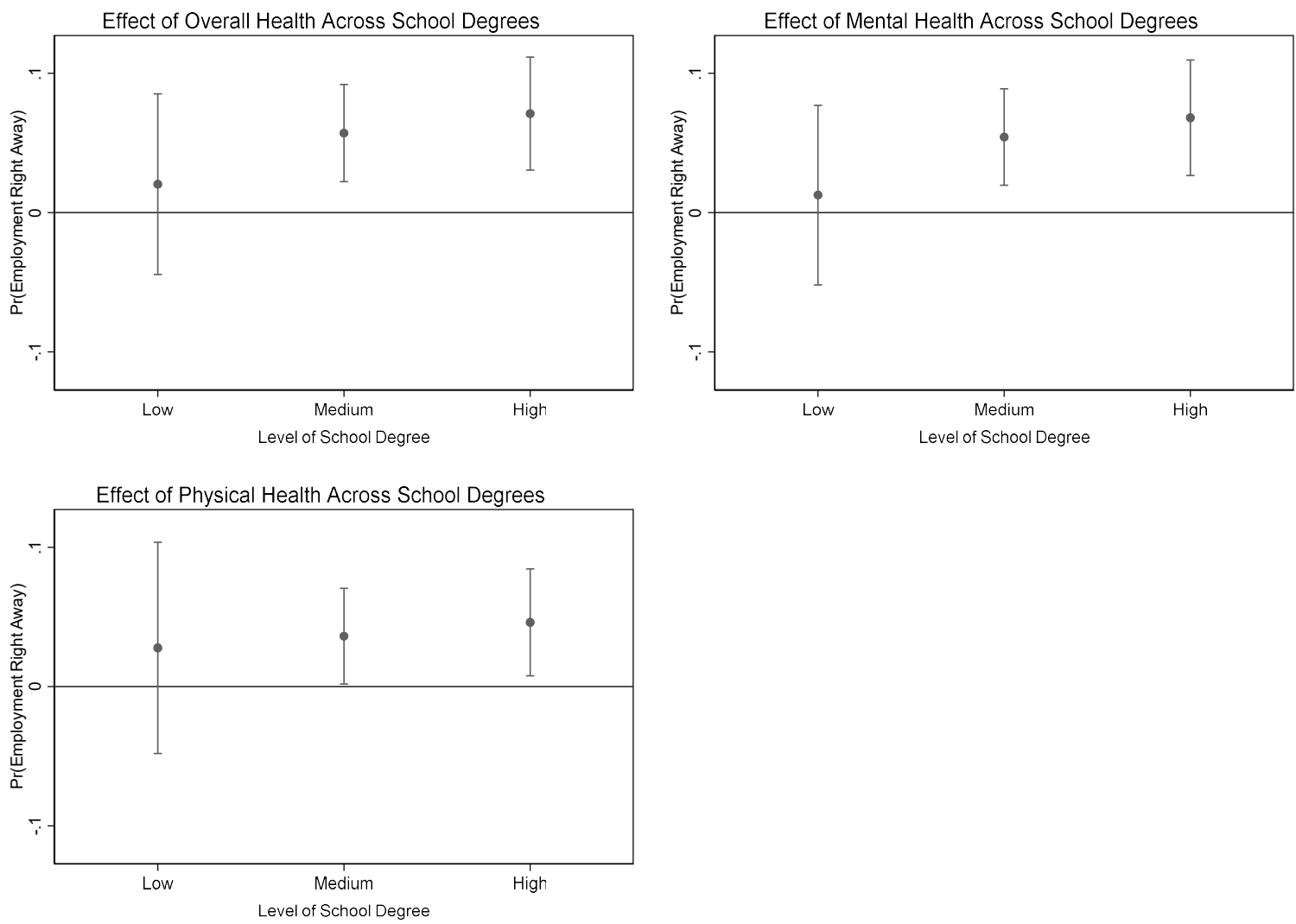

Figure 3. Effect of overall, physical and mental health on finding a first job without employment interruption according to educational level. Full regression results in Table A4 of the Appendix. Source: Own calculations based on data from the Jugalo Study. 


\section{Discussion and Conclusions}

This study uses a novel dataset combining survey and register data to investigate how mental and physical health, personality disorders and work commitment relate to school-to-work transition outcomes among graduates of apprenticeship training. The study reveals the following main results.

First, only physical health is important for transitions to a first job within six months. Second, the overall health of individuals is positively correlated with finding a first job without employment interruptions. Moreover, our results indicate that the association between personality traits and gapless transitions appears to be mediated by individual and firm characteristics, while overall health is directly associated with gapless transitions to a first job. Third, coping abilities appear to be important drivers of transitions into decent first jobs. However, models including important individual and training firm characteristics suggest that these factors mediate the association between coping abilities and transitions to a decent first job. Fourth, while the heterogeneity according to educational-level analyses reveals a moderate interaction effect on the relationship between educational levels and physical health for transitions to first jobs within six months, the effect of overall health on gapless transitions to a first job depends on educational levels. The overall health effect is almost nonexistent for individuals with the lowest educational degrees in Germany but very pronounced for individuals with a Realschule or Abitur degree. Moreover, our results of this workaround suggest that the identified pattern follows the mental health pattern.

In sum, our findings indicate a double disadvantage for low-achieving youth (Jacob \& Solga, 2015) in the German apprenticeship system. In particular, our findings on the transition to decent first jobs indicate that selection into training firms based on health, personality disorders, and work commitment drives our results. Furthermore, the heterogeneity analysis hints at a cumulative advantage for already privileged groups in the school-to-work transition. As starting points in the labor market are crucial for career development (e.g., Scherer 2004), selection based on health, personality disorders and work commitment after individuals finish high school has the potential to introduce long-term inequality in the labor market.

Overall, our results suggest that noncognitive constructs like health, personality disorders and work commitment have the potential to shed new light on school-to-work transitions. Moreover, our findings indicate that policy makers when developing schemes for disadvantaged youth should acknowledge these factors. Our analyses indicate that in particular mental health is likely to interact with the "usual suspects", which are normally used by career counseling agencies to identify disadvantage. Additionally, supplementary factor analysis reveals that the employed health measures (HSCL-10 and SF-12) approximate one latent construct. Thus, at young ages, it appears that individuals' mental and physical health are strongly correlated. 
A shortcoming of our work is that we cannot control for preselection in early childhood and during general schooling. Research has shown that both factors are highly important in explaining health selection (e.g., McLeod \& Fettes, 2007). However, we find associations while controlling for school grades and educational degrees, which indicates that some constructs under study have additional explanatory power. Moreover, we consider only a short-term perspective. Future work should investigate the medium- and long-term influence of health, personality disorders and work commitment. Additionally, future work should incorporate individuals from school-based training and higher education to further validate the study's main findings. Furthermore, more insights in subgroup analyses are needed because research suggests that, for instance, health is unevenly distributed across the social structure (e.g., Elo 2009). 


\section{References}

Becker, R., \& Blossfeld, H. P. (2021). Changes in the returns to education at entry into the labour market in West Germany. Longitudinal and Life Course Studies.

Berge, P. vom, Frodermann, C., Schmucker, A. \& Seth, S. (2021). Sample of Integrated Labour Market Biographies (SIAB) 1975 - 2019. FDZ Datenreport, 01/2021 (en), Nürnberg. DOI:10.5164/IAB.FDZD.2101.en.v1

Bielby, D. D. V., \& Bielby, W. T. (1984). Work commitment, sex-role attitudes, and women's employment. American Sociological Review, 234-247.

Bol, T., \& Weeden, K. A. (2015). Occupational closure and wage inequality in Germany and the United Kingdom. European Sociological Review, 31(3), 354-369.

Borgna, C., \& Struffolino, E. (2017). Pushed or pulled? Girls and boys facing early school leaving risk in Italy. Social Science Research, 61, 298-313.

Campbell, C. (2015). High school dropouts after they exit school: Challenges and directions for sociological research. Sociology Compass, 9(7), 619-629.

Cornaglia, F., Crivellaro, E., \& McNally, S. (2015). Mental health and education decisions. Labour Economics, 33, 112.

Dannefer, D. (2003). Cumulative advantage/disadvantage and the life course: Cross-fertilizing age and social science theory. The Journals of Gerontology Series B: Psychological Sciences and Social Sciences, 58(6), 327S337.

Derogatis, L. R., Lipmann R. S., Rickels, K., Uhlenhut, E. H. \& Covi L. (1974). The Hopkins symptom checklist (HSCL): a self-report symptom inventory. Behavioural Science 19(1): 1-15.

Diehl, C., Friedrich, M., \& Hall, A. (2009). Jugendliche ausländischer Herkunft beim Übergang in die Berufsausbildung: VomWollen, Können und Dürfen/Young Adults with Immigrant Background and Their Transition to the German System of Vocational Training. The Role of Preferences, Resources, and Opportunities. Zeitschrift für Soziologie, 38(1), 48-67.

Dietrich, Hans; Abraham, Martin; Abraham, Martin (Hrsg.); Hinz, Thomas (Hrsg.) (2018): Übergänge in Ausbildung und Arbeitsmarkt. In: Arbeitsmarktsoziologie. Probleme, Theorien, empirische Befunde, Wiesbaden: Springer VS, S. 77-116.

Dietrich, Hans; Henseke, Golo; Achatz, Juliane; Anger, Silke; Christoph, Bernhard; Patzina, Alexander Youth unemployment in Germany and the United Kingdom in times of Covid-19 (Series "Tracking youth joblessness during the Covid-19 crisis"). In: IAB-Forum H.04.08.2021

Dietrich, H., Pfeifer, H., \& Wenzelmann, F. (2016). The more they spend, the more I earn?: firms' training investments and post-training wages of apprentices. Economics of Education Working Paper Series, (0116).

Dietrich, H., Patzina, A., \& Kretschmer, S. (2019). Soziale Herkunft, Lebensverlaufsereignisse und die verspätete Aufnahme einer beruflichen Ausbildung formal Geringqualifizierter. KZfSS Kölner Zeitschrift für Soziologie und Sozialpsychologie, 71(3), 357-383.

Di Giunta, L., Alessandri, G., Gerbino, M., Kanacri, P. L., Zuffiano, A., \& Caprara, G. V. (2013). The determinants of scholastic achievement: The contribution of personality traits, self-esteem, and academic selfefficacy. Learning and individual Differences, 27, 102-108.

DiPrete, T. A., \& Eirich, G. M. (2006). Cumulative advantage as a mechanism for inequality: A review of theoretical and empirical developments. Annual Review of Sociology, 32, 271-297.

Duchesne, S., \& Ratelle, C. (2010). Parental behaviors and adolescents' achievement goals at the beginning of middle school: Emotional problems as potential mediators. Journal of educational psychology, 102(2), 497.

Eisenberg, D., Golberstein, E., \& Hunt, J. B. (2009). Mental health and academic success in college. The BE Journal of Economic Analysis \& Policy, 9(1). 
Elo, I. T. (2009). Social class differentials in health and mortality: Patterns and explanations in comparative perspective. Annual review of sociology, 35, 553-572.

Evensen, M. (2019). Adolescent Mental Health Problems, Behaviour Penalties, and Distributional Variation in Educational Achievement. European Sociological Review, 35(4), 474-490.

Forster, A. G., Bol, T., \& Van de Werfhorst, H. G. (2016). Vocational education and employment over the life cycle. Sociological Science, 3, 473-494.

Fossati, F., Wilson, A., \& Bonoli, G. (2020). What signals do employers use when hiring? Evidence from a survey experiment in the apprenticeship market. European Sociological Review, 36(5), 760-779.

Gangl, M., \& Ziefle, A. (2015). The making of a good woman: Extended parental leave entitlements and mothers' work commitment in Germany. American Journal of Sociology, 121(2), 511-563.

Gebel, M. (2015). Labor market instability, labor market entry, and early career development. Emerging trends in the social and behavioral sciences: An interdisciplinary, searchable, and linkable resource, 1-16.

Haas, S. A. (2006). Health selection and the process of social stratification: the effect of childhood health on socioeconomic attainment. Journal of health and social behavior, 47(4), 339-354.

Hansen, A. T., Hvidman, U., \& Sievertsen, H. H. (2021). Grades and Employer Learning (No. 21/740). School of Economics, University of Bristol, UK.

Hillmert, S., Hartung, A., \& Weßling, K. (2017). A decomposition of local labour-market conditions and their relevance for inequalities in transitions to vocational training. European Sociological Review, 33(4), 534550 .

Hoeschler, P., \& Backes-Gellner, U. (2017). The relative importance of personal characteristics for the hiring of young workers. Swiss Leading House Working Paper Series, (142).

Holtmann, A. C., Menze, L., \& Solga, H. (2017). Persistent disadvantages or new opportunities? The role of agency and structural constraints for low-achieving adolescents' school-to-work transitions. Journal of youth and adolescence, 46(10), 2091-2113.

Jacob, M., \& Solga, H. (2015). Germany's vocational education and training system in transformation: changes in the participation of low-and high-achieving youth over time. European Sociological Review, 31(2), 161-171.

Jahoda, M., Lazarsfeld P. F. \& Zeisel H. (1932/1971). Marienthal: The sociography of an unemployed community. Chicago and New York (Aldine, Atherton).

Kleinert, C., \& Jacob, M. (2013). Demographic changes, labor markets and their consequences on post-schooltransitions in West Germany 1975-2005. Research in Social Stratification and Mobility, 32, 65-83.

Kratz, F., \& Patzina, A. (2020). Endogenous Selection Bias and Cumulative Inequality over the Life Course: Evidence from Educational Inequality in Subjective Well-Being. European Sociological Review, 36(3), 333-350.

Kratz, F., Patzina, A., Kleinert, C., \& Dietrich, H. (2019). Vocational education and employment: Explaining cohort variations in life course patterns. Social Inclusion, 7(3), 224-253.

Krug, G., \& Eberl, A. (2018). What explains the negative effect of unemployment on health? An analysis accounting for reverse causality. Research in Social Stratification and Mobility, 55, 25-39.

Leopold, L., \& Leopold, T. (2018). Education and health across lives and cohorts: a study of cumulative (dis) advantage and its rising importance in Germany. Journal of Health and Social Behavior, 59(1), 94-112.

Leykin, Y., Roberts, C. S., \& DeRubeis, R. J. (2011). Decision-making and depressive symptomatology. Cognitive therapy and research, 35(4), 333-341.

Lindemann, K., \& Gangl, M. (2019). Parental unemployment and the transition to vocational training in Germany: interaction of household and regional sources of disadvantage. European Sociological Review, 35(5), 684700 .

McLeod, J. D., \& Fettes, D. L. (2007). Trajectories of failure: The educational careers of children with mental health problems. American journal of sociology, 113(3), 653-701. 
McLeod, J. D., Uemura, R., \& Rohrman, S. (2012). Adolescent mental health, behavior problems, and academic achievement. Journal of health and social behavior, 53(4), 482-497.

Müller, W. and Gangl, M. (Eds.) (2003). Transitions from education to work in Europe: the integration of youth into EU labour markets. Oxford: University Press on Demand.

Ng-Knight, T., \& Schoon, I. (2017). Can locus of control compensate for socioeconomic adversity in the transition from school to work?. Journal of Youth and Adolescence, 46(10), 2114-2128.

Patzina, A., \& Wydra-Somaggio, G. (2020). Early Careers of Dropouts from Vocational Training: Signals, Human Capital Formation, and Training Firms. European Sociological Review, 36(5), 741-759.

Pinquart, M., Juang, L. P., \& Silbereisen, R. K. (2003). Self-efficacy and successful school-to-work transition: A longitudinal study. Journal of vocational behavior, 63(3), 329-346.

Protsch, P., \& Dieckhoff, M. (2011). What matters in the transition from school to vocational training in Germany: Educational credentials, cognitive abilities or personality?. European Societies, 13(1), 69-91.

Protsch, P., \& Solga, H. (2015). How employers use signals of cognitive and noncognitive skills at labour market entry: insights from field experiments. European Sociological Review, 31(5), 521-532.

Radoschewski M., \& Bellach B.-M. (1999). Der SF-36 im Bundes-Gesundheitssurvey - Möglichkeiten und Anforderungen der Nutzung auf der Bevölkerungsebene. Das Gesundheitswesen 61(Sonderheft 2), $191-199$.

Roepke, A. M., \& Seligman, M. E. (2016). Depression and prospection. British Journal of Clinical Psychology, 55(1), 23-48.

Ross, C. E., \& Mirowsky, J. (2011). The interaction of personal and parental education on health. Social Science \& Medicine, 72(4), 591-599.

Scherer, S. (2004). Stepping-stones or traps? The consequences of labour market entry positions on future careers in West Germany, Great Britain and Italy. Work, employment and society, 18(2), 369-394.

Scherer, S. (2005). Patterns of labour market entry-long wait or career instability? An empirical comparison of Italy, Great Britain and West Germany. European Sociological Review, 21(5), 427-440.

Schoon, I., \& Mortimer, J. (2017). Youth and the Great Recession: Are values, achievement orientation and outlook to the future affected?. International Journal of Psychology, 52(1), 1-8.

Seibert, H., Hupka-Brunner, S., \& Imdorf, C. (2009). Wie Ausbildungssysteme Chancen verteilen. KZfSS Kölner Zeitschrift für Soziologie und Sozialpsychologie, 61(4), 595-620.

Solga, H., Protsch, P., Ebner, C., \& Brzinsky-Fay, C. (2014). The German vocational education and training system: Its institutional configuration, strengths, and challenges (No. SP I 2014-502). WZB Discussion Paper.

Warr P., Cook J. \& Wall T. (1979). Scales for the measurement of some work attitudes and aspects of psychological well-being. Journal of Occupational Psychology, 52(2), 129-48.

Wydra-Somaggio, G., \& Seibert, H. (2010). Signalwirkung von Lehrabschlüssen: Einkommensunterschiede von Ausbildungsabsolventen beim Berufseinstieg. Sozialer Fortschritt, 296-305.

Parker, G., Hadzi-Pavlovic, D., Both, L., Kumar, S., Wilhelm, K., \& Olley, A. (2004). Measuring disordered personality functioning: To love and to work reprised. Acta Psychiatrica Scandinavica, 110(3), 230-239.

Reissner, V., Mühe, B., Wellenbrock, S., Kuhnigk, O., Kis, B., Dietrich, H., \& Hebebrand, J. (2014). DSM-IV-TR Axes-I and II mental disorders in a representative and referred sample of unemployed youths-Results from a psychiatric liaison service in a job centre. European Psychiatry, 29(4), 239-245.

Zheng, H. (2017). Why does college education matter? Unveiling the contributions of selection factors. Social science research, 68, 59-73.

Zimmermann, E., \& Skrobanek, J. (2015). „Glaube an dich, dann schaffst du es auch?!“-Die Rolle der allgemeinen Selbstwirksamkeitsüberzeugung im Ausbildungsübergang. Zeitschrift für Erziehungswissenschaft, 18(2), 351-374. 


\section{Appendix}

Table A1. Finding a first job within six months.

(1) 0.004

(0.006)

Panel $A$

Anxiety and depression

Mental health

Physical health

Overall health

Work Commitment Scale

Coping ability

Cooperativeness

Controls

Online interview (ref. paper and pencil)

Constant

Adj.-R ${ }^{2}$

F-Value

Panel B

Anxiety and depression

Mental health

Physical health

Overall health

Work Commitment Scale

Coping ability

Cooperativeness

Controls

Dummy for male gender

Dummy for migration background

Social origin

(dummy for former welfare benefit receipt)

Dummy for East Germany

Birth year (ref. 1991)

1992

1993
(2)

(3)

(4)

(5)

(6)
0.003

$0.015^{* *}$
$(0.006)$
0.010
$(0.006)$

0.002

(0.006)
$-0.001$

(0.006)

0.000

(0.006)

\begin{tabular}{llllll}
$0.025^{* *}$ & $-0.024^{* *}$ & $-0.025^{* *}$ & $-0.024^{* *}$ & $-0.025^{* *}$ & $-0.025^{* *}$ \\
$0.012)$ & $(0.012)$ & $(0.012)$ & $(0.012)$ & $(0.012)$ & $(0.012)$ \\
$0.974^{* * *}$ & $0.974^{* *}$ & $0.974^{* * *}$ & $0.974^{* * *}$ & $0.974^{* * *}$ & $0.974^{* * *}$ \\
$0.009)$ & $(0.009)$ & $(0.009)$ & $(0.009)$ & $(0.009)$ & $(0.009)$ \\
\hline 0.002 & 0.002 & 0.008 & 0.005 & 0.002 & 0.001 \\
2.322 & 2.248 & 5.169 & 3.452 & 2.218 & 1.425 \\
\hline
\end{tabular}

0.006

(0.006)

0.002

(0.006)

(0.006)

0.008

(0.006)

0.002

(0.006)

$-0.004$

(0.007)

$-0.001$

(0.007)

$\begin{array}{cccccc}-0.009 & -0.012 & -0.013 & -0.014 & -0.012 & -0.011 \\ (0.013) & (0.013) & (0.012) & (0.013) & (0.013) & (0.013) \\ -0.031 & -0.031 & -0.029 & -0.030 & -0.031 & -0.031 \\ (0.042) & (0.042) & (0.042) & (0.042) & (0.042) & (0.042) \\ -0.028 & -0.026 & -0.025 & -0.025 & -0.027 & -0.028 \\ (0.020) & (0.021) & (0.020) & (0.021) & (0.020) & (0.020) \\ & & & & & \\ -0.020 & -0.018 & -0.017 & -0.018 & -0.018 & -0.019 \\ (0.019) & (0.019) & (0.018) & (0.018) & (0.019) & (0.019) \\ & & & & & \\ -0.059 & -0.056 & -0.058 & -0.057 & -0.056 & -0.056 \\ (0.054) & (0.054) & (0.054) & (0.054) & (0.054) & (0.054) \\ -0.058 & -0.059 & -0.059 & -0.060 & -0.059 & -0.058 \\ (0.050) & (0.050) & (0.050) & (0.050) & (0.050) & (0.050)\end{array}$




\begin{tabular}{|c|c|c|c|c|c|c|}
\hline 1994 & $\begin{array}{l}-0.077 \\
(0.050)\end{array}$ & $\begin{array}{l}-0.077 \\
(0.050)\end{array}$ & $\begin{array}{l}-0.076 \\
(0.050)\end{array}$ & $\begin{array}{l}-0.078 \\
(0.050)\end{array}$ & $\begin{array}{l}-0.077 \\
(0.050)\end{array}$ & $\begin{array}{l}-0.076 \\
(0.050)\end{array}$ \\
\hline 1995 & $\begin{array}{l}-0.057 \\
(0.050)\end{array}$ & $\begin{array}{l}-0.058 \\
(0.050)\end{array}$ & $\begin{array}{l}-0.056 \\
(0.050)\end{array}$ & $\begin{array}{l}-0.058 \\
(0.050)\end{array}$ & $\begin{array}{l}-0.058 \\
(0.050)\end{array}$ & $\begin{array}{l}-0.057 \\
(0.050)\end{array}$ \\
\hline 1996 & $\begin{array}{l}-0.025 \\
(0.052)\end{array}$ & $\begin{array}{l}-0.026 \\
(0.052)\end{array}$ & $\begin{array}{l}-0.023 \\
(0.052)\end{array}$ & $\begin{array}{l}-0.025 \\
(0.052)\end{array}$ & $\begin{array}{l}-0.026 \\
(0.052)\end{array}$ & $\begin{array}{l}-0.025 \\
(0.052)\end{array}$ \\
\hline 1997 & $\begin{array}{l}-0.014 \\
(0.052)\end{array}$ & $\begin{array}{l}-0.015 \\
(0.052)\end{array}$ & $\begin{array}{l}-0.015 \\
(0.052)\end{array}$ & $\begin{array}{l}-0.016 \\
(0.052)\end{array}$ & $\begin{array}{l}-0.015 \\
(0.052)\end{array}$ & $\begin{array}{c}-0.014 \\
(0.052)\end{array}$ \\
\hline 1998 & $\begin{array}{l}-0.100 \\
(0.069)\end{array}$ & $\begin{array}{c}-0.101 \\
(0.069)\end{array}$ & $\begin{array}{l}-0.101 \\
(0.069)\end{array}$ & $\begin{array}{l}-0.103 \\
(0.069)\end{array}$ & $\begin{array}{l}-0.101 \\
(0.069)\end{array}$ & $\begin{array}{l}-0.100 \\
(0.069)\end{array}$ \\
\hline Educational level (ref. Haup & & & & & & \\
\hline Realscl & $\begin{array}{c}0.011 \\
(0.022)\end{array}$ & $\begin{array}{c}0.010 \\
(0.022)\end{array}$ & $\begin{array}{c}0.006 \\
(0.022)\end{array}$ & $\begin{array}{c}0.008 \\
(0.022)\end{array}$ & $\begin{array}{c}0.011 \\
(0.022)\end{array}$ & $\begin{array}{c}0.011 \\
(0.022)\end{array}$ \\
\hline Gymnasium/high & $\begin{array}{c}0.034 \\
(0.028)\end{array}$ & $\begin{array}{c}0.032 \\
(0.028)\end{array}$ & $\begin{array}{c}0.027 \\
(0.028)\end{array}$ & $\begin{array}{c}0.030 \\
(0.028)\end{array}$ & $\begin{array}{c}0.033 \\
(0.028)\end{array}$ & $\begin{array}{c}0.034 \\
(0.028)\end{array}$ \\
\hline Missing information & $\begin{array}{c}0.037 \\
(0.114)\end{array}$ & $\begin{array}{c}0.040 \\
(0.114)\end{array}$ & $\begin{array}{c}0.037 \\
(0.113)\end{array}$ & $\begin{array}{c}0.039 \\
(0.113)\end{array}$ & $\begin{array}{c}0.041 \\
(0.114)\end{array}$ & $\begin{array}{c}0.042 \\
(0.114)\end{array}$ \\
\hline $\begin{array}{l}\text { Educational perfor } \\
\text { (ref. GPA 2.6-3.5) }\end{array}$ & & & & & & \\
\hline GPA $1.0-1.5$ & $\begin{array}{l}-0.002 \\
(0.028)\end{array}$ & $\begin{array}{l}-0.002 \\
(0.028)\end{array}$ & $\begin{array}{l}-0.001 \\
(0.028)\end{array}$ & $\begin{array}{l}-0.002 \\
(0.028)\end{array}$ & $\begin{array}{l}-0.002 \\
(0.028)\end{array}$ & $\begin{array}{c}-0.001 \\
(0.028)\end{array}$ \\
\hline GPA 1.6-2.5 & $\begin{array}{l}-0.001 \\
(0.013)\end{array}$ & $\begin{array}{c}-0.001 \\
(0.013)\end{array}$ & $\begin{array}{l}-0.003 \\
(0.013)\end{array}$ & $\begin{array}{l}-0.002 \\
(0.013)\end{array}$ & $\begin{array}{l}-0.002 \\
(0.013)\end{array}$ & $\begin{array}{l}-0.001 \\
(0.013)\end{array}$ \\
\hline GPA 3.6-5.0 & $\begin{array}{c}0.012 \\
(0.041)\end{array}$ & $\begin{array}{c}0.011 \\
(0.041)\end{array}$ & $\begin{array}{c}0.008 \\
(0.041)\end{array}$ & $\begin{array}{c}0.010 \\
(0.041)\end{array}$ & $\begin{array}{c}0.012 \\
(0.041)\end{array}$ & $\begin{array}{c}0.011 \\
(0.041)\end{array}$ \\
\hline Missing information & $\begin{array}{c}0.048 \\
(0.074)\end{array}$ & $\begin{array}{c}0.042 \\
(0.074)\end{array}$ & $\begin{array}{c}0.037 \\
(0.074)\end{array}$ & $\begin{array}{c}0.039 \\
(0.074)\end{array}$ & $\begin{array}{c}0.042 \\
(0.074)\end{array}$ & $\begin{array}{c}0.043 \\
(0.074)\end{array}$ \\
\hline Dummy for second VET & $\begin{array}{l}-0.002 \\
(0.018)\end{array}$ & $\begin{array}{c}-0.001 \\
(0.018)\end{array}$ & $\begin{array}{l}-0.000 \\
(0.018)\end{array}$ & $\begin{array}{l}-0.001 \\
(0.018)\end{array}$ & $\begin{array}{c}-0.002 \\
(0.018)\end{array}$ & $\begin{array}{c}-0.001 \\
(0.018)\end{array}$ \\
\hline $\begin{array}{l}\text { Dummy for missing information on } \\
\text { second VET }\end{array}$ & $\begin{array}{c}0.039 \\
(0.065)\end{array}$ & $\begin{array}{c}0.036 \\
(0.065)\end{array}$ & $\begin{array}{c}0.037 \\
(0.065)\end{array}$ & $\begin{array}{c}0.036 \\
(0.065)\end{array}$ & $\begin{array}{c}0.036 \\
(0.065)\end{array}$ & $\begin{array}{c}0.036 \\
(0.065)\end{array}$ \\
\hline Training firm size & $\begin{array}{c}0.000 \\
(0.000)\end{array}$ & $\begin{array}{c}0.000 \\
(0.000)\end{array}$ & $\begin{array}{c}0.000 \\
(0.000)\end{array}$ & $\begin{array}{c}0.000 \\
(0.000)\end{array}$ & $\begin{array}{c}0.000 \\
(0.000)\end{array}$ & $\begin{array}{c}0.000 \\
(0.000)\end{array}$ \\
\hline Training firm wage level & $\begin{array}{c}0.000 \\
(0.000)\end{array}$ & $\begin{array}{c}0.000 \\
(0.000)\end{array}$ & $\begin{array}{c}0.000 \\
(0.000)\end{array}$ & $\begin{array}{c}0.000 \\
(0.000)\end{array}$ & $\begin{array}{c}0.000 \\
(0.000)\end{array}$ & $\begin{array}{c}0.000 \\
(0.000)\end{array}$ \\
\hline Online interview (ref. paper and pencil) & $\begin{array}{l}-0.023^{*} \\
(0.012)\end{array}$ & $\begin{array}{l}-0.022^{*} \\
(0.012)\end{array}$ & $\begin{array}{l}-0.022^{*} \\
(0.012)\end{array}$ & $\begin{array}{l}-0.022^{*} \\
(0.012)\end{array}$ & $\begin{array}{l}-0.022^{*} \\
(0.012)\end{array}$ & $\begin{array}{l}-0.023^{*} \\
(0.012)\end{array}$ \\
\hline Constant & $\begin{array}{l}0.979^{* * *} \\
(0.057)\end{array}$ & $\begin{array}{l}0.982^{* * *} \\
(0.057)\end{array}$ & $\begin{array}{l}0.988^{* * *} \\
(0.057)\end{array}$ & $\begin{array}{l}0.986^{* * *} \\
(0.057)\end{array}$ & $\begin{array}{l}0.982^{* * *} \\
(0.057)\end{array}$ & $\begin{array}{l}0.979^{* * *} \\
(0.057)\end{array}$ \\
\hline $\mathrm{Npe}$ & 1,0 & & & 1,061 & & 1,061 \\
\hline & & & 0 & 0.003 & 0.002 & 0.001 \\
\hline F-value & 1.123 & 1.081 & 1.243 & 1.144 & 1.083 & 1.050 \\
\hline
\end{tabular}

Note: Results from linear probability models. Standard errors in parentheses; significance levels: ${ }^{*} \mathrm{p}<0.10,{ }^{* *} \mathrm{p}<0.05$, and ${ }^{* * *}$ $\mathrm{p}<0.01$. 
Table A2. Finding a first job without employment interruption.

\begin{tabular}{|c|c|c|c|c|c|c|c|}
\hline & $(1)$ & $(2)$ & $(3)$ & $(4)$ & $(5)$ & (6) & Full \\
\hline \multicolumn{8}{|l|}{ Panel $A$} \\
\hline Anxiety and depression & $\begin{array}{c}-0.054^{* * *} \\
(0.012)\end{array}$ & & & & & & \\
\hline Mental health & & $\begin{array}{l}0.062^{* * *} \\
(0.012)\end{array}$ & & & & & \\
\hline Physical health & & & $\begin{array}{l}0.051^{* * *} \\
(0.012)\end{array}$ & & & & \\
\hline Overall health & & & & $\begin{array}{l}0.068^{* * *} \\
(0.012)\end{array}$ & & & $\begin{array}{l}0.061^{* * *} \\
(0.013)\end{array}$ \\
\hline Work Commitment Scale & & & & & $\begin{array}{c}0.019 \\
(0.012)\end{array}$ & & \\
\hline Coping ability & & & & & & $\begin{array}{c}0.030^{* *} \\
(0.013)\end{array}$ & $\begin{array}{c}0.011 \\
(0.013)\end{array}$ \\
\hline Cooperativeness & & & & & & $\begin{array}{c}0.023^{*} \\
(0.013)\end{array}$ & $\begin{array}{c}0.020 \\
(0.013)\end{array}$ \\
\hline \multicolumn{8}{|l|}{ Controls } \\
\hline $\begin{array}{l}\text { Online interview } \\
\text { (ref. paper and pencil) }\end{array}$ & $\begin{array}{l}-0.024 \\
(0.024)\end{array}$ & $\begin{array}{l}-0.021 \\
(0.024)\end{array}$ & $\begin{array}{l}-0.026 \\
(0.024)\end{array}$ & $\begin{array}{l}-0.023 \\
(0.024)\end{array}$ & $\begin{array}{l}-0.028 \\
(0.025)\end{array}$ & $\begin{array}{l}-0.019 \\
(0.025)\end{array}$ & $\begin{array}{c}-0.019 \\
(0.024)\end{array}$ \\
\hline Constant & $\begin{array}{l}0.813^{* * *} \\
(0.018) \\
\end{array}$ & $\begin{array}{l}0.811^{* * *} \\
(0.018) \\
\end{array}$ & $\begin{array}{l}0.814^{* * *} \\
(0.018) \\
\end{array}$ & $\begin{array}{l}0.812^{* * *} \\
(0.018) \\
\end{array}$ & $\begin{array}{l}0.815^{* * *} \\
(0.018) \\
\end{array}$ & $\begin{array}{l}0.810^{* * *} \\
(0.018) \\
\end{array}$ & $\begin{array}{l}0.810^{* * *} \\
(0.018) \\
\end{array}$ \\
\hline $\begin{array}{l}\text { Adj.- } \mathrm{R}^{2} \\
\text { F-Value }\end{array}$ & $\begin{array}{c}0.017 \\
10.296 \\
\end{array}$ & $\begin{array}{c}0.023 \\
13.442 \\
\end{array}$ & $\begin{array}{l}0.016 \\
9.350 \\
\end{array}$ & $\begin{array}{c}0.028 \\
16.431 \\
\end{array}$ & $\begin{array}{l}0.001 \\
1.671 \\
\end{array}$ & $\begin{array}{l}0.010 \\
4.637 \\
\end{array}$ & $\begin{array}{l}0.030 \\
9.256 \\
\end{array}$ \\
\hline \multicolumn{8}{|l|}{ Panel B } \\
\hline Anxiety and depression & $\begin{array}{c}-0.047^{* * *} \\
(0.013)\end{array}$ & & & & & & \\
\hline Mental health & & $\begin{array}{l}0.055^{* * *} \\
(0.012)\end{array}$ & & & & & \\
\hline Physical health & & & $\begin{array}{l}0.041^{* * *} \\
(0.012)\end{array}$ & & & & \\
\hline Overall health & & & & $\begin{array}{l}0.059^{* * *} \\
(0.012)\end{array}$ & & & $\begin{array}{l}0.056^{* * *} \\
(0.013)\end{array}$ \\
\hline Work Commitment Scale & & & & & $\begin{array}{c}0.015 \\
(0.012)\end{array}$ & & \\
\hline Coping ability & & & & & & $\begin{array}{c}0.016 \\
(0.013)\end{array}$ & $\begin{array}{c}0.001 \\
(0.014)\end{array}$ \\
\hline Cooperativeness & & & & & & $\begin{array}{c}0.020 \\
(0.013)\end{array}$ & $\begin{array}{c}0.015 \\
(0.013)\end{array}$ \\
\hline \multicolumn{8}{|l|}{ Controls } \\
\hline Dummy for male gender & $\begin{array}{l}-0.045^{*} \\
(0.026)\end{array}$ & $\begin{array}{c}-0.039 \\
(0.025)\end{array}$ & $\begin{array}{c}-0.025 \\
(0.025)\end{array}$ & $\begin{array}{c}-0.037 \\
(0.025)\end{array}$ & $\begin{array}{c}-0.019 \\
(0.025)\end{array}$ & $\begin{array}{c}-0.017 \\
(0.026)\end{array}$ & $\begin{array}{c}-0.030 \\
(0.026)\end{array}$ \\
\hline Dummy for migration background & $\begin{array}{c}0.036 \\
(0.085)\end{array}$ & $\begin{array}{c}0.032 \\
(0.085)\end{array}$ & $\begin{array}{c}0.040 \\
(0.086)\end{array}$ & $\begin{array}{c}0.038 \\
(0.085)\end{array}$ & $\begin{array}{c}0.034 \\
(0.086)\end{array}$ & $\begin{array}{c}0.031 \\
(0.086)\end{array}$ & $\begin{array}{c}0.037 \\
(0.085)\end{array}$ \\
\hline $\begin{array}{l}\text { Social origin } \\
\text { (dummy for former welfare } \\
\text { benefit receipt) }\end{array}$ & $\begin{array}{c}-0.159^{* * *} \\
(0.041)\end{array}$ & $\begin{array}{c}-0.152^{* * *} \\
(0.041)\end{array}$ & $\begin{array}{c}-0.161^{* * *} \\
(0.041)\end{array}$ & $\begin{array}{c}-0.151^{* * *} \\
(0.041)\end{array}$ & $\begin{array}{c}-0.169^{* * *} \\
(0.042)\end{array}$ & $\begin{array}{c}-0.164^{* * *} \\
(0.042)\end{array}$ & $\begin{array}{c}-0.150^{* * *} \\
(0.041)\end{array}$ \\
\hline Dummy for East Germany & $\begin{array}{c}-0.089^{* *} \\
(0.038)\end{array}$ & $\begin{array}{c}-0.097^{* * *} \\
(0.037)\end{array}$ & $\begin{array}{c}-0.097^{* * *} \\
(0.037)\end{array}$ & $\begin{array}{c}-0.095^{* *} \\
(0.037)\end{array}$ & $\begin{array}{c}-0.098^{* * *} \\
(0.038)\end{array}$ & $\begin{array}{l}-0.092^{* *} \\
(0.038)\end{array}$ & $\begin{array}{c}-0.092^{* *} \\
(0.037)\end{array}$ \\
\hline \multicolumn{8}{|l|}{ Birth year (ref. 1991) } \\
\hline 1992 & $\begin{array}{l}-0.119 \\
(0.110)\end{array}$ & $\begin{array}{l}-0.141 \\
(0.110)\end{array}$ & $\begin{array}{l}-0.143 \\
(0.110)\end{array}$ & $\begin{array}{l}-0.145 \\
(0.109)\end{array}$ & $\begin{array}{l}-0.139 \\
(0.111)\end{array}$ & $\begin{array}{l}-0.144 \\
(0.111)\end{array}$ & $\begin{array}{l}-0.150 \\
(0.110)\end{array}$ \\
\hline 1993 & $\begin{array}{c}-0.087 \\
(0.102)\end{array}$ & $\begin{array}{l}-0.107 \\
(0.102)\end{array}$ & $\begin{array}{c}-0.090 \\
(0.102)\end{array}$ & $\begin{array}{c}-0.103 \\
(0.102)\end{array}$ & $\begin{array}{c}-0.091 \\
(0.103)\end{array}$ & $\begin{array}{c}-0.093 \\
(0.102)\end{array}$ & $\begin{array}{c}-0.105 \\
(0.102)\end{array}$ \\
\hline 1994 & $\begin{array}{c}-0.130 \\
(0.100)\end{array}$ & $\begin{array}{c}-0.145 \\
(0.100)\end{array}$ & $\begin{array}{c}-0.127 \\
(0.100)\end{array}$ & $\begin{array}{c}-0.138 \\
(0.100)\end{array}$ & $\begin{array}{c}-0.136 \\
(0.101)\end{array}$ & $\begin{array}{c}-0.140 \\
(0.101)\end{array}$ & $\begin{array}{c}-0.142 \\
(0.100)\end{array}$ \\
\hline 1995 & -0.112 & -0.125 & -0.109 & -0.118 & -0.118 & -0.120 & -0.121 \\
\hline
\end{tabular}




\begin{tabular}{|c|c|c|c|c|c|c|c|}
\hline & $(0.101)$ & $(0.100)$ & $(0.101)$ & $(0.100)$ & $(0.101)$ & $(0.101)$ & $(0.100)$ \\
\hline \multirow[t]{2}{*}{1996} & -0.036 & -0.044 & -0.024 & -0.034 & -0.037 & -0.038 & -0.036 \\
\hline & $(0.104)$ & $(0.104)$ & $(0.105)$ & $(0.104)$ & $(0.105)$ & $(0.105)$ & $(0.104)$ \\
\hline \multirow[t]{2}{*}{1997} & -0.054 & -0.063 & -0.048 & -0.059 & -0.051 & -0.056 & -0.061 \\
\hline & $(0.106)$ & $(0.106)$ & $(0.106)$ & $(0.105)$ & $(0.106)$ & $(0.106)$ & $\begin{array}{l}(0.105) \\
-0148\end{array}$ \\
\hline 1998 & $\begin{array}{c}-0.140 \\
(0.139)\end{array}$ & $\begin{array}{l}-0.155 \\
(0.139)\end{array}$ & $\begin{array}{l}-0.135 \\
(0.140)\end{array}$ & $\begin{array}{l}-0.150 \\
(0.139)\end{array}$ & $\begin{array}{c}-0.133 \\
(0.140)\end{array}$ & $\begin{array}{l}-0.136 \\
(0.140)\end{array}$ & $\begin{array}{l}-0.148 \\
(0.139)\end{array}$ \\
\hline \multicolumn{8}{|l|}{$\begin{array}{l}\text { Educational level } \\
\text { (ref. Hauptschule/low) }\end{array}$} \\
\hline Realschule/medium & $\begin{array}{c}0.032 \\
(0.045)\end{array}$ & $\begin{array}{c}0.025 \\
(0.045)\end{array}$ & $\begin{array}{c}0.017 \\
(0.046)\end{array}$ & $\begin{array}{c}0.015 \\
(0.045)\end{array}$ & $\begin{array}{c}0.038 \\
(0.046)\end{array}$ & $\begin{array}{c}0.027 \\
(0.046)\end{array}$ & $\begin{array}{c}0.014 \\
(0.045)\end{array}$ \\
\hline Gymnasium/high & $\begin{array}{c}0.047 \\
(0.056)\end{array}$ & $\begin{array}{c}0.046 \\
(0.056)\end{array}$ & $\begin{array}{c}0.036 \\
(0.056)\end{array}$ & $\begin{array}{c}0.035 \\
(0.056)\end{array}$ & $\begin{array}{c}0.057 \\
(0.056)\end{array}$ & $\begin{array}{c}0.044 \\
(0.056)\end{array}$ & $\begin{array}{c}0.033 \\
(0.056)\end{array}$ \\
\hline Missing information & $\begin{array}{l}-0.093 \\
(0.230)\end{array}$ & $\begin{array}{l}-0.118 \\
(0.229)\end{array}$ & $\begin{array}{l}-0.127 \\
(0.230)\end{array}$ & $\begin{array}{l}-0.126 \\
(0.229)\end{array}$ & $\begin{array}{l}-0.113 \\
(0.231)\end{array}$ & $\begin{array}{l}-0.135 \\
(0.231)\end{array}$ & $\begin{array}{l}-0.139 \\
(0.229)\end{array}$ \\
\hline \multicolumn{8}{|l|}{$\begin{array}{l}\text { Educational performance } \\
\text { (ref. GPA 2.6-3.5) }\end{array}$} \\
\hline GPA 1.0-1.5 & $\begin{array}{c}0.034 \\
(0.057)\end{array}$ & $\begin{array}{c}0.027 \\
(0.057)\end{array}$ & $\begin{array}{c}0.032 \\
(0.057)\end{array}$ & $\begin{array}{c}0.029 \\
(0.057)\end{array}$ & $\begin{array}{c}0.028 \\
(0.057)\end{array}$ & $\begin{array}{c}0.025 \\
(0.057)\end{array}$ & $\begin{array}{c}0.029 \\
(0.057)\end{array}$ \\
\hline GPA 1.6-2.5 & $\begin{array}{c}0.037 \\
(0.026)\end{array}$ & $\begin{array}{c}0.032 \\
(0.026)\end{array}$ & $\begin{array}{c}0.031 \\
(0.026)\end{array}$ & $\begin{array}{c}0.029 \\
(0.026)\end{array}$ & $\begin{array}{c}0.035 \\
(0.027)\end{array}$ & $\begin{array}{c}0.031 \\
(0.027)\end{array}$ & $\begin{array}{c}0.027 \\
(0.026)\end{array}$ \\
\hline GPA 3.6-5.0 & $\begin{array}{l}-0.031 \\
(0.083)\end{array}$ & $\begin{array}{l}-0.031 \\
(0.083)\end{array}$ & $\begin{array}{l}-0.039 \\
(0.083)\end{array}$ & $\begin{array}{l}-0.040 \\
(0.083)\end{array}$ & $\begin{array}{l}-0.021 \\
(0.084)\end{array}$ & $\begin{array}{l}-0.024 \\
(0.084)\end{array}$ & $\begin{array}{l}-0.038 \\
(0.083)\end{array}$ \\
\hline Missing information & $\begin{array}{c}0.183 \\
(0.150)\end{array}$ & $\begin{array}{c}0.202 \\
(0.149)\end{array}$ & $\begin{array}{c}0.200 \\
(0.150)\end{array}$ & $\begin{array}{c}0.191 \\
(0.149)\end{array}$ & $\begin{array}{c}0.218 \\
(0.150)\end{array}$ & $\begin{array}{c}0.205 \\
(0.151)\end{array}$ & $\begin{array}{c}0.181 \\
(0.149)\end{array}$ \\
\hline Dummy for second VET & $\begin{array}{c}0.013 \\
(0.037)\end{array}$ & $\begin{array}{c}0.012 \\
(0.037)\end{array}$ & $\begin{array}{c}0.010 \\
(0.037)\end{array}$ & $\begin{array}{c}0.013 \\
(0.037)\end{array}$ & $\begin{array}{c}0.004 \\
(0.037)\end{array}$ & $\begin{array}{c}0.005 \\
(0.037)\end{array}$ & $\begin{array}{c}0.012 \\
(0.037)\end{array}$ \\
\hline \multirow{2}{*}{$\begin{array}{l}\text { Dummy for missing information } \\
\text { on } \\
\text { second VET }\end{array}$} & 0.065 & 0.087 & 0.091 & 0.089 & 0.088 & 0.094 & 0.095 \\
\hline & $(0.131)$ & $(0.131)$ & $(0.131)$ & $(0.131)$ & $(0.132)$ & $(0.132)$ & $(0.131)$ \\
\hline Training firm size & $\begin{array}{c}0.000 \\
(0.000)\end{array}$ & $\begin{array}{c}0.000 \\
(0.000)\end{array}$ & $\begin{array}{l}-0.000 \\
(0.000)\end{array}$ & $\begin{array}{c}0.000 \\
(0.000)\end{array}$ & $\begin{array}{l}0.000 \\
(0.000)\end{array}$ & $\begin{array}{c}0.000 \\
(0.000)\end{array}$ & $\begin{array}{c}0.000 \\
(0.000)\end{array}$ \\
\hline Training firm wage level & $\begin{array}{l}0.001^{* * *} \\
(0.000)\end{array}$ & $\begin{array}{l}0.001^{* * *} \\
(0.000)\end{array}$ & $\begin{array}{l}0.001^{* * *} \\
(0.000)\end{array}$ & $\begin{array}{l}0.001^{* * *} \\
(0.000)\end{array}$ & $\begin{array}{l}0.001^{* * *} \\
(0.000)\end{array}$ & $\begin{array}{l}0.001^{* * *} \\
(0.000)\end{array}$ & $\begin{array}{l}0.001^{* * *} \\
(0.000)\end{array}$ \\
\hline $\begin{array}{l}\text { Online interview } \\
\text { (ref. paper and pencil) }\end{array}$ & $\begin{array}{l}-0.027 \\
(0.025)\end{array}$ & $\begin{array}{l}-0.025 \\
(0.024)\end{array}$ & $\begin{array}{l}-0.031 \\
(0.025)\end{array}$ & $\begin{array}{l}-0.027 \\
(0.024)\end{array}$ & $\begin{array}{l}-0.032 \\
(0.025)\end{array}$ & $\begin{array}{l}-0.025 \\
(0.025)\end{array}$ & $\begin{array}{l}-0.024 \\
(0.024)\end{array}$ \\
\hline Constant & $\begin{array}{l}0.771^{* * *} \\
(0.115)\end{array}$ & $\begin{array}{l}0.783^{* * *} \\
(0.114)\end{array}$ & $\begin{array}{l}0.779^{* * *} \\
(0.115)\end{array}$ & $\begin{array}{l}0.792^{* * *} \\
(0.114)\end{array}$ & $\begin{array}{l}0.760^{* * *} \\
(0.115)\end{array}$ & $\begin{array}{l}0.772^{* * *} \\
(0.115)\end{array}$ & $\begin{array}{l}0.793^{* * *} \\
(0.114)\end{array}$ \\
\hline $\mathrm{N}$ persons & 1,061 & 1,061 & 1,061 & 1,061 & 1,061 & 1,061 & 1,061 \\
\hline Adj. $-R^{2}$ & 0.053 & 0.059 & 0.050 & 0.061 & 0.041 & 0.044 & 0.060 \\
\hline F-value & 3.452 & 3.749 & 3.326 & 3.863 & 2.902 & 2.963 & 3.621 \\
\hline
\end{tabular}




\section{(1)}

(2)

\section{(3)}

(4)

(5)

(6)

Full

\begin{tabular}{|c|c|c|c|c|c|c|c|}
\hline $\begin{array}{l}\text { Panel } A \\
\text { Anxiety and depression }\end{array}$ & $\begin{array}{l}-0.026^{*} \\
(0.014)\end{array}$ & & & & & & \\
\hline Mental health & & $\begin{array}{c}0.017 \\
(0.014)\end{array}$ & & & & & \\
\hline Physical health & & & $\begin{array}{l}0.042^{* * *} \\
(0.014)\end{array}$ & & & & \\
\hline Overall health & & & & $\begin{array}{l}0.034^{* *} \\
(0.014)\end{array}$ & & & $\begin{array}{c}0.020 \\
(0.015)\end{array}$ \\
\hline Work Commitment Scale & & & & & $\begin{array}{c}0.025^{*} \\
(0.014)\end{array}$ & & $\begin{array}{c}0.014 \\
(0.014)\end{array}$ \\
\hline Coping ability & & & & & & $\begin{array}{l}0.045^{* * *} \\
(0.015)\end{array}$ & $\begin{array}{l}0.036^{* *} \\
(0.016)\end{array}$ \\
\hline Cooperativeness & & & & & & $\begin{array}{c}0.011 \\
(0.015)\end{array}$ & $\begin{array}{c}0.007 \\
(0.015)\end{array}$ \\
\hline Controls & & & & & & & \\
\hline $\begin{array}{l}\text { Online interview } \\
\text { (ref. paper and pencil) }\end{array}$ & $\begin{array}{c}0.010 \\
(0.028)\end{array}$ & $\begin{array}{c}0.011 \\
(0.028)\end{array}$ & $\begin{array}{c}0.009 \\
(0.028)\end{array}$ & $\begin{array}{c}0.011 \\
(0.028)\end{array}$ & $\begin{array}{c}0.006 \\
(0.028)\end{array}$ & $\begin{array}{c}0.016 \\
(0.028)\end{array}$ & $\begin{array}{c}0.013 \\
(0.028)\end{array}$ \\
\hline Constant & $\begin{array}{l}0.712^{* * *} \\
(0.020) \\
\end{array}$ & $\begin{array}{l}0.712^{* * *} \\
(0.020) \\
\end{array}$ & $\begin{array}{l}0.713^{* * *} \\
(0.020) \\
\end{array}$ & $\begin{array}{l}0.712^{* * *} \\
(0.020) \\
\end{array}$ & $\begin{array}{l}0.714^{* * *} \\
(0.020) \\
\end{array}$ & $\begin{array}{l}0.709^{* * *} \\
(0.020) \\
\end{array}$ & $\begin{array}{l}0.710^{* * *} \\
(0.020)\end{array}$ \\
\hline $\begin{array}{l}\text { Adj.-R } \\
\text { F-value }\end{array}$ & $\begin{array}{l}0.002 \\
1.841 \\
\end{array}$ & $\begin{array}{c}-0.000 \\
0.844 \\
\end{array}$ & $\begin{array}{l}0.007 \\
4.680 \\
\end{array}$ & $\begin{array}{l}0.004 \\
3.058 \\
\end{array}$ & $\begin{array}{l}0.001 \\
1.711 \\
\end{array}$ & $\begin{array}{l}0.009 \\
4.372 \\
\end{array}$ & $\begin{array}{l}0.010 \\
3.166 \\
\end{array}$ \\
\hline Panel $B$ & & & & & & & \\
\hline Anxiety and depression & $\begin{array}{l}-0.013 \\
(0.014)\end{array}$ & & & & & & \\
\hline Mental health & & $\begin{array}{c}0.006 \\
(0.014)\end{array}$ & & & & & \\
\hline Physical health & & & $\begin{array}{c}0.020 \\
(0.014)\end{array}$ & & & & \\
\hline Overall health & & & & $\begin{array}{c}0.015 \\
(0.014)\end{array}$ & & & $\begin{array}{c}0.009 \\
(0.014)\end{array}$ \\
\hline Work Commitment Scale & & & & & $\begin{array}{c}0.018 \\
(0.014)\end{array}$ & & $\begin{array}{c}0.014 \\
(0.014)\end{array}$ \\
\hline Coping ability & & & & & & $\begin{array}{c}0.022 \\
(0.015)\end{array}$ & $\begin{array}{c}0.017 \\
(0.016)\end{array}$ \\
\hline Cooperativeness & & & & & & $\begin{array}{c}0.002 \\
(0.015)\end{array}$ & $\begin{array}{l}-0.001 \\
(0.015)\end{array}$ \\
\hline Controls & & & & & & & \\
\hline Dummy for male gender & $\begin{array}{l}-0.010 \\
(0.029)\end{array}$ & $\begin{array}{l}-0.006 \\
(0.029)\end{array}$ & $\begin{array}{c}-0.006 \\
(0.028)\end{array}$ & $\begin{array}{l}-0.008 \\
(0.028)\end{array}$ & $\begin{array}{l}-0.001 \\
(0.028)\end{array}$ & $\begin{array}{l}-0.008 \\
(0.029)\end{array}$ & $\begin{array}{l}-0.008 \\
(0.030)\end{array}$ \\
\hline Dummy for migration background & $\begin{array}{l}-0.072 \\
(0.096)\end{array}$ & $\begin{array}{l}-0.072 \\
(0.096)\end{array}$ & $\begin{array}{l}-0.069 \\
(0.096)\end{array}$ & $\begin{array}{l}-0.071 \\
(0.096)\end{array}$ & $\begin{array}{l}-0.071 \\
(0.096)\end{array}$ & $\begin{array}{l}-0.073 \\
(0.096)\end{array}$ & $\begin{array}{l}-0.071 \\
(0.096)\end{array}$ \\
\hline $\begin{array}{l}\text { Social origin } \\
\text { (dummy for former welfare } \\
\text { benefit receipt) }\end{array}$ & $\begin{array}{l}-0.078^{*} \\
(0.046)\end{array}$ & $\begin{array}{l}-0.079^{*} \\
(0.046)\end{array}$ & $\begin{array}{l}-0.077^{*} \\
(0.046)\end{array}$ & $\begin{array}{l}-0.076 \\
(0.046)\end{array}$ & $\begin{array}{l}-0.082^{*} \\
(0.046)\end{array}$ & $\begin{array}{l}-0.076^{*} \\
(0.046)\end{array}$ & $\begin{array}{l}-0.076 \\
(0.046)\end{array}$ \\
\hline Dummy for East Germany & $\begin{array}{l}-0.162^{* * *} \\
(0.042)\end{array}$ & $\begin{array}{c}-0.165^{* * *} \\
(0.042)\end{array}$ & $\begin{array}{c}-0.163^{* * *} \\
(0.042)\end{array}$ & $\begin{array}{c}-0.164^{* * *} \\
(0.042)\end{array}$ & $\begin{array}{l}-0.162^{* * *} \\
(0.042)\end{array}$ & $\begin{array}{l}-0.159^{* * *} \\
(0.042)\end{array}$ & $\begin{array}{l}-0.158^{* * * *} \\
(0.042)\end{array}$ \\
\hline Birth year (ref. 1991) & & & & & & & \\
\hline 1992 & $\begin{array}{c}0.060 \\
(0.123)\end{array}$ & $\begin{array}{c}0.055 \\
(0.123)\end{array}$ & $\begin{array}{c}0.052 \\
(0.123)\end{array}$ & $\begin{array}{c}0.053 \\
(0.123)\end{array}$ & $\begin{array}{c}0.052 \\
(0.123)\end{array}$ & $\begin{array}{c}0.055 \\
(0.123)\end{array}$ & $\begin{array}{c}0.052 \\
(0.123)\end{array}$ \\
\hline 1993 & $\begin{array}{c}0.084 \\
(0.114)\end{array}$ & $\begin{array}{c}0.081 \\
(0.114)\end{array}$ & $\begin{array}{c}0.082 \\
(0.114)\end{array}$ & $\begin{array}{c}0.080 \\
(0.114)\end{array}$ & $\begin{array}{c}0.080 \\
(0.114)\end{array}$ & $\begin{array}{c}0.082 \\
(0.114)\end{array}$ & $\begin{array}{c}0.078 \\
(0.114)\end{array}$ \\
\hline 1994 & $\begin{array}{c}0.068 \\
(0.112)\end{array}$ & $\begin{array}{c}0.066 \\
(0.112)\end{array}$ & $\begin{array}{c}0.070 \\
(0.112)\end{array}$ & $\begin{array}{c}0.066 \\
(0.112)\end{array}$ & $\begin{array}{c}0.063 \\
(0.112)\end{array}$ & $\begin{array}{c}0.064 \\
(0.112)\end{array}$ & $\begin{array}{c}0.061 \\
(0.112)\end{array}$ \\
\hline 1995 & 0.119 & 0.117 & 0.120 & 0.117 & 0.113 & 0.115 & 0.112 \\
\hline
\end{tabular}




\begin{tabular}{|c|c|c|c|c|c|c|c|}
\hline & $(0.113)$ & $(0.113)$ & $(0.113)$ & $(0.113)$ & $(0.113)$ & $(0.113)$ & $(0.113)$ \\
\hline \multirow[t]{2}{*}{1996} & 0.132 & 0.132 & 0.137 & 0.133 & 0.127 & 0.129 & 0.125 \\
\hline & (0.117) & $(0.117)$ & $(0.117)$ & (0.117) & $(0.117)$ & $(0.117)$ & $(0.117)$ \\
\hline \multirow[t]{2}{*}{1997} & 0.156 & 0.156 & 0.158 & 0.155 & 0.155 & 0.152 & 0.149 \\
\hline & $(0.118)$ & $(0.118)$ & $(0.118)$ & $(0.118)$ & $(0.118)$ & $(0.118)$ & $(0.118)$ \\
\hline 1998 & $\begin{array}{c}0.072 \\
(0.156)\end{array}$ & $\begin{array}{c}0.071 \\
(0.156)\end{array}$ & $\begin{array}{c}0.073 \\
(0.156)\end{array}$ & $\begin{array}{c}0.070 \\
(0.156)\end{array}$ & $\begin{array}{c}0.074 \\
(0.156)\end{array}$ & $\begin{array}{c}0.070 \\
(0.156)\end{array}$ & $\begin{array}{c}0.069 \\
(0.156)\end{array}$ \\
\hline \multicolumn{8}{|l|}{$\begin{array}{l}\text { Educational level } \\
\text { (ref. Hauptschule/low) }\end{array}$} \\
\hline Realschule/medium & $\begin{array}{l}0.147^{* * *} \\
(0.051)\end{array}$ & $\begin{array}{l}0.146^{* * *} \\
(0.051)\end{array}$ & $\begin{array}{l}0.139^{* * *} \\
(0.051)\end{array}$ & $\begin{array}{l}0.143^{* * *} \\
(0.051)\end{array}$ & $\begin{array}{l}0.153^{* * *} \\
(0.051)\end{array}$ & $\begin{array}{l}0.142^{* *} \\
(0.051)\end{array}$ & $\begin{array}{l}0.145^{* * *} \\
(0.051)\end{array}$ \\
\hline Gymnasium/high & $\begin{array}{l}0.251^{* * *} \\
(0.063)\end{array}$ & $\begin{array}{l}0.252^{* * *} \\
(0.063)\end{array}$ & $\begin{array}{l}0.244^{* * *} \\
(0.063)\end{array}$ & $\begin{array}{l}0.248^{* * *} \\
(0.063)\end{array}$ & $\begin{array}{l}0.255^{* * *} \\
(0.062)\end{array}$ & $\begin{array}{l}0.243^{* * *} \\
(0.063)\end{array}$ & $\begin{array}{l}0.244^{* * *} \\
(0.063)\end{array}$ \\
\hline Missing information & $\begin{array}{c}0.132 \\
(0.257)\end{array}$ & $\begin{array}{c}0.126 \\
(0.257)\end{array}$ & $\begin{array}{c}0.121 \\
(0.257)\end{array}$ & $\begin{array}{c}0.124 \\
(0.257)\end{array}$ & $\begin{array}{c}0.129 \\
(0.257)\end{array}$ & $\begin{array}{c}0.122 \\
(0.257)\end{array}$ & $\begin{array}{c}0.125 \\
(0.257)\end{array}$ \\
\hline \multicolumn{8}{|l|}{$\begin{array}{l}\text { Educational performance } \\
\text { (ref. GPA 2.6-3.5) }\end{array}$} \\
\hline GPA $1.0-1.5$ & $\begin{array}{c}0.026 \\
(0.064)\end{array}$ & $\begin{array}{c}0.025 \\
(0.064)\end{array}$ & $\begin{array}{c}0.026 \\
(0.064)\end{array}$ & $\begin{array}{c}0.025 \\
(0.064)\end{array}$ & $\begin{array}{c}0.023 \\
(0.064)\end{array}$ & $\begin{array}{c}0.019 \\
(0.064)\end{array}$ & $\begin{array}{c}0.019 \\
(0.064)\end{array}$ \\
\hline GPA 1.6-2.5 & $\begin{array}{c}0.049^{*} \\
(0.029)\end{array}$ & $\begin{array}{c}0.048 \\
(0.029)\end{array}$ & $\begin{array}{c}0.046 \\
(0.029)\end{array}$ & $\begin{array}{c}0.047 \\
(0.029)\end{array}$ & $\begin{array}{c}0.046 \\
(0.029)\end{array}$ & $\begin{array}{c}0.045 \\
(0.030)\end{array}$ & $\begin{array}{c}0.043 \\
(0.030)\end{array}$ \\
\hline GPA 3.6-5.0 & $\begin{array}{c}0.058 \\
(0.093)\end{array}$ & $\begin{array}{c}0.058 \\
(0.093)\end{array}$ & $\begin{array}{c}0.053 \\
(0.093)\end{array}$ & $\begin{array}{c}0.056 \\
(0.093)\end{array}$ & $\begin{array}{c}0.065 \\
(0.093)\end{array}$ & $\begin{array}{c}0.060 \\
(0.093)\end{array}$ & $\begin{array}{c}0.062 \\
(0.093)\end{array}$ \\
\hline Missing information & $\begin{array}{c}0.220 \\
(0.168)\end{array}$ & $\begin{array}{c}0.228 \\
(0.167)\end{array}$ & $\begin{array}{c}0.220 \\
(0.167)\end{array}$ & $\begin{array}{c}0.223 \\
(0.167)\end{array}$ & $\begin{array}{c}0.227 \\
(0.167)\end{array}$ & $\begin{array}{c}0.228 \\
(0.168)\end{array}$ & $\begin{array}{c}0.224 \\
(0.168)\end{array}$ \\
\hline Dummy for second VET & $\begin{array}{l}-0.002 \\
(0.041)\end{array}$ & $\begin{array}{l}-0.003 \\
(0.041)\end{array}$ & $\begin{array}{l}-0.002 \\
(0.041)\end{array}$ & $\begin{array}{l}-0.002 \\
(0.041)\end{array}$ & $\begin{array}{l}-0.007 \\
(0.041)\end{array}$ & $\begin{array}{l}-0.006 \\
(0.041)\end{array}$ & $\begin{array}{l}-0.007 \\
(0.042)\end{array}$ \\
\hline $\begin{array}{l}\text { Dummy for missing information } \\
\text { on }\end{array}$ & 0.178 & 0.184 & 0.186 & 0.185 & 0.184 & 0.183 & 0.182 \\
\hline second VET & $(0.147)$ & $(0.147)$ & $(0.147)$ & $(0.147)$ & $(0.147)$ & $(0.147)$ & $(0.147)$ \\
\hline Training firm size & $\begin{array}{l}-0.000 \\
(0.000)\end{array}$ & $\begin{array}{l}-0.000 \\
(0.000)\end{array}$ & $\begin{array}{l}-0.000 \\
(0.000)\end{array}$ & $\begin{array}{l}-0.000 \\
(0.000)\end{array}$ & $\begin{array}{l}-0.000 \\
(0.000)\end{array}$ & $\begin{array}{l}-0.000 \\
(0.000)\end{array}$ & $\begin{array}{l}-0.000 \\
(0.000)\end{array}$ \\
\hline Training firm wage level & $\begin{array}{l}0.001^{* * *} \\
(0.000)\end{array}$ & $\begin{array}{l}0.001^{* * *} \\
(0.000)\end{array}$ & $\begin{array}{l}0.001^{* * *} \\
(0.000)\end{array}$ & $\begin{array}{l}0.001^{* * *} \\
(0.000)\end{array}$ & $\begin{array}{l}0.001^{* * *} \\
(0.000)\end{array}$ & $\begin{array}{l}0.001^{* * *} \\
(0.000)\end{array}$ & $\begin{array}{l}0.001^{* * *} \\
(0.000)\end{array}$ \\
\hline $\begin{array}{l}\text { Online interview } \\
\text { (ref. paper and pencil) }\end{array}$ & $\begin{array}{l}-0.002 \\
(0.027)\end{array}$ & $\begin{array}{l}-0.002 \\
(0.027)\end{array}$ & $\begin{array}{l}-0.003 \\
(0.027)\end{array}$ & $\begin{array}{l}-0.002 \\
(0.027)\end{array}$ & $\begin{array}{l}-0.005 \\
(0.027)\end{array}$ & $\begin{array}{c}0.001 \\
(0.028)\end{array}$ & $\begin{array}{l}-0.001 \\
(0.028)\end{array}$ \\
\hline Constant & $\begin{array}{l}0.265^{* *} \\
(0.128)\end{array}$ & $\begin{array}{l}0.265^{* *} \\
(0.128)\end{array}$ & $\begin{array}{l}0.272^{* *} \\
(0.128)\end{array}$ & $\begin{array}{l}0.270^{* *} \\
(0.128)\end{array}$ & $\begin{array}{l}0.266^{* *} \\
(0.128)\end{array}$ & $\begin{array}{l}0.279^{* *} \\
(0.128)\end{array}$ & $\begin{array}{l}0.283^{* *} \\
(0.129)\end{array}$ \\
\hline N persons & 1,061 & 1,061 & 1,061 & 1,061 & 1,061 & 1,061 & 1,061 \\
\hline Adj.-R² & 0.064 & 0.064 & 0.066 & 0.065 & 0.065 & 0.065 & 0.065 \\
\hline F-value & 4.040 & 4.014 & 4.097 & 4.056 & 4.084 & 3.961 & 3.711 \\
\hline
\end{tabular}




\begin{tabular}{|c|c|c|c|c|}
\hline & $(1)$ & $(2)$ & $(3)$ & $(4)$ \\
\hline Mental health & & & $\begin{array}{l}0.068^{* * *} \\
(0.021)\end{array}$ & \\
\hline Physical health & $\begin{array}{c}0.000 \\
(0.010)\end{array}$ & & & $\begin{array}{c}0.046^{* *} \\
(0.020)\end{array}$ \\
\hline Overall health & & $\begin{array}{l}0.071^{* * *} \\
(0.021)\end{array}$ & & \\
\hline Coping & & $\begin{array}{c}0.000 \\
(0.014)\end{array}$ & $\begin{array}{c}-0.001 \\
(0.014)\end{array}$ & $\begin{array}{c}0.012 \\
(0.013)\end{array}$ \\
\hline Cooperativeness & & $\begin{array}{c}0.015 \\
(0.013)\end{array}$ & $\begin{array}{c}0.014 \\
(0.013)\end{array}$ & $\begin{array}{c}0.019 \\
(0.013)\end{array}$ \\
\hline \multicolumn{5}{|l|}{ Educational level (ref. Gymnasium/high) } \\
\hline Hauptschule/low & $\begin{array}{c}-0.022 \\
(0.028)\end{array}$ & $\begin{array}{c}-0.041 \\
(0.056)\end{array}$ & $\begin{array}{c}-0.047 \\
(0.056)\end{array}$ & $\begin{array}{c}-0.033 \\
(0.058)\end{array}$ \\
\hline Realschule/medium & $\begin{array}{c}-0.022 \\
(0.020)\end{array}$ & $\begin{array}{c}-0.018 \\
(0.040)\end{array}$ & $\begin{array}{c}-0.020 \\
(0.040)\end{array}$ & $\begin{array}{c}-0.016 \\
(0.040)\end{array}$ \\
\hline Missing information & $\begin{array}{c}0.004 \\
(0.114)\end{array}$ & $\begin{array}{c}-0.198 \\
(0.230)\end{array}$ & $\begin{array}{c}-0.185 \\
(0.229)\end{array}$ & $\begin{array}{c}-0.210 \\
(0.232)\end{array}$ \\
\hline \multicolumn{5}{|l|}{ Interaction of educational level and physical health } \\
\hline Hauptschule/low X physical health & $\begin{array}{c}0.027 \\
(0.021)\end{array}$ & & & $\begin{array}{c}-0.018 \\
(0.043)\end{array}$ \\
\hline Realschule/medium X physical health & $\begin{array}{c}0.018 \\
(0.013)\end{array}$ & & & $\begin{array}{c}-0.010 \\
(0.026)\end{array}$ \\
\hline Missing information $\mathrm{X}$ physical health & $\begin{array}{c}-0.009 \\
(0.073)\end{array}$ & & & $\begin{array}{c}-0.190 \\
(0.147)\end{array}$ \\
\hline \multicolumn{5}{|l|}{ Interaction of educational level and overall health } \\
\hline Hauptschule/low X overall health & & $\begin{array}{c}-0.051 \\
(0.039)\end{array}$ & & \\
\hline Realschule/medium X overall health & & $\begin{array}{c}-0.014 \\
(0.027)\end{array}$ & & \\
\hline Missing information X overall health & & $\begin{array}{c}-0.221 \\
(0.159)\end{array}$ & & \\
\hline \multicolumn{5}{|l|}{ Interaction of educational level and mental health } \\
\hline Hauptschule/low X mental health & & & $\begin{array}{c}-0.055 \\
(0.039)\end{array}$ & \\
\hline Realschule/medium X mental health & & & $\begin{array}{c}-0.014 \\
(0.026)\end{array}$ & \\
\hline Missing information X mental health & & & $\begin{array}{c}-0.293 \\
(0.248)\end{array}$ & \\
\hline Dummy for male gender & $\begin{array}{c}-0.012 \\
(0.012)\end{array}$ & $\begin{array}{c}-0.033 \\
(0.026)\end{array}$ & $\begin{array}{c}-0.035 \\
(0.026)\end{array}$ & $\begin{array}{c}-0.021 \\
(0.026)\end{array}$ \\
\hline Dummy for migration background & $\begin{array}{c}-0.026 \\
(0.042)\end{array}$ & $\begin{array}{c}0.035 \\
(0.085)\end{array}$ & $\begin{array}{c}0.032 \\
(0.085)\end{array}$ & $\begin{array}{c}0.036 \\
(0.086)\end{array}$ \\
\hline Social origin (dummy for former welfare benefit receipt) & $\begin{array}{c}-0.022 \\
(0.021)\end{array}$ & $\begin{array}{c}-0.153^{* * *} \\
(0.041)\end{array}$ & $\begin{array}{c}-0.154^{* * *} \\
(0.041)\end{array}$ & $\begin{array}{r}-0.158^{* *} \\
(0.042)\end{array}$ \\
\hline Dummy for East Germany & $\begin{array}{c}-0.016 \\
(0.019)\end{array}$ & $\begin{array}{l}-0.091^{* *} \\
(0.037)\end{array}$ & $\begin{array}{c}-0.093^{* *} \\
(0.037)\end{array}$ & $\begin{array}{c}-0.090^{* *} \\
(0.038)\end{array}$ \\
\hline \multicolumn{5}{|l|}{ Birth year (ref. 1991) } \\
\hline 1992 & $\begin{array}{c}-0.053 \\
(0.054)\end{array}$ & $\begin{array}{c}-0.157 \\
(0.110)\end{array}$ & $\begin{array}{c}-0.153 \\
(0.110)\end{array}$ & $\begin{array}{c}-0.153 \\
(0.110)\end{array}$ \\
\hline 1993 & $\begin{array}{c}-0.055 \\
(0.050)\end{array}$ & $\begin{array}{c}-0.114 \\
(0.102)\end{array}$ & $\begin{array}{c}-0.118 \\
(0.102)\end{array}$ & $\begin{array}{c}-0.097 \\
(0.102)\end{array}$ \\
\hline 1994 & $\begin{array}{c}-0.072 \\
(0.050)\end{array}$ & $\begin{array}{c}-0.150 \\
(0.100)\end{array}$ & $\begin{array}{c}-0.157 \\
(0.100)\end{array}$ & $\begin{array}{c}-0.137 \\
(0.100)\end{array}$ \\
\hline 1995 & $\begin{array}{c}-0.051 \\
(0.050)\end{array}$ & $\begin{array}{c}-0.130 \\
(0.101)\end{array}$ & $\begin{array}{c}-0.136 \\
(0.101)\end{array}$ & $\begin{array}{r}-0.118 \\
(0.101)\end{array}$ \\
\hline 1996 & $\begin{array}{c}-0.019 \\
(0.052)\end{array}$ & $\begin{array}{c}-0.045 \\
(0.104)\end{array}$ & $\begin{array}{c}-0.054 \\
(0.104)\end{array}$ & $\begin{array}{c}-0.032 \\
(0.105)\end{array}$ \\
\hline
\end{tabular}


1997

1998

Educational performance (ref. GPA 2.6-3.5)

GPA 1.0-1.5

GPA 1.6-2.5

GPA 3.6-5.0

Missing information

Dummy for second VET

Dummy for missing information on second VET

Training firm size

Training firm wage level

Online interview (ref. paper and pencil)

Constant

Constant

N Persons

Adj.- $\mathrm{R}^{2}$

F-Value

Note: Coefficie

\begin{tabular}{cccc}
-0.012 & -0.069 & -0.074 & -0.055 \\
$(0.052)$ & $(0.106)$ & $(0.106)$ & $(0.106)$ \\
-0.098 & -0.154 & -0.156 & -0.138 \\
$(0.069)$ & $(0.139)$ & $(0.139)$ & $(0.140)$ \\
& & & \\
-0.002 & 0.029 & 0.026 & 0.028 \\
$(0.028)$ & $(0.057)$ & $(0.057)$ & $(0.057)$ \\
-0.003 & 0.027 & 0.029 & 0.027 \\
$(0.013)$ & $(0.026)$ & $(0.026)$ & $(0.027)$ \\
0.004 & -0.035 & -0.028 & -0.034 \\
$(0.041)$ & $(0.083)$ & $(0.083)$ & $(0.084)$ \\
0.033 & 0.184 & 0.191 & 0.188 \\
$(0.074)$ & $(0.149)$ & $(0.149)$ & $(0.150)$ \\
-0.001 & 0.013 & 0.012 & 0.009 \\
$(0.018)$ & $(0.037)$ & $(0.037)$ & $(0.037)$ \\
0.038 & 0.091 & 0.087 & 0.097 \\
$(0.065)$ & $(0.131)$ & $(0.131)$ & $(0.131)$ \\
0.000 & 0.000 & 0.000 & -0.000 \\
$(0.000)$ & $(0.000)$ & $(0.000)$ & $(0.000)$ \\
0.000 & $0.001^{* * *}$ & $0.001^{* * *}$ & $0.001^{* * *}$ \\
$(0.000)$ & $(0.000)$ & $(0.000)$ & $(0.000)$ \\
$-0.022^{*}$ & -0.026 & -0.025 & -0.027 \\
$(0.012)$ & $(0.025)$ & $(0.025)$ & $(0.025)$ \\
$1.011^{* * *}$ & $0.837^{* * *}$ & $0.839^{* * *}$ & $0.821^{* * *}$ \\
$(0.051)$ & $(0.103)$ & $(0.104)$ & $(0.104)$ \\
\hline 1061 & 1061 & 1061 & 1061 \\
0.005 & 0.061 & 0.058 & 0.051 \\
1.207 & 3.367 & 3.260 & 2.959 \\
\hline$<0.10, * *$ & $<0.05, * * *$ & $<0.01$. &
\end{tabular}

$p<0.10,{ }^{* *} p<0.05,{ }^{* * *} p<0.01$. 